\title{
Impacts of future land use and land cover change on mid-21st-century surface ozone air quality: distinguishing between the biogeophysical and biogeochemical effects
}

\author{
Lang Wang ${ }^{1,2}$, Amos P. K. Tai ${ }^{1,3,4}$, Chi-Yung Tam ${ }^{1,3}$, Mehliyar Sadiq ${ }^{1,3}$, Peng Wang ${ }^{3}$, and Kevin K. W. Cheung ${ }^{5,6}$ \\ ${ }^{1}$ Institute of Environment, Energy and Sustainability, The Chinese University of Hong Kong, \\ Shatin, Hong Kong SAR, China \\ ${ }^{2}$ Department of Geography and Resource Management, The Chinese University of Hong Kong, \\ Shatin, Hong Kong SAR, China \\ ${ }^{3}$ Earth System Science Programme, Faculty of Science, The Chinese University of Hong Kong, \\ Shatin, Hong Kong SAR, China \\ ${ }^{4}$ Partner State Key Laboratory of Agrobiotechnology, The Chinese University of Hong Kong, \\ Shatin, Hong Kong SAR, China \\ ${ }^{5}$ Department of Earth and Environmental Sciences, Macquarie University, Sydney, 2109, Australia \\ ${ }^{6}$ Climate Research, NSW Department of Planning, Industry and Environment, Sydney, Australia
}

Correspondence: Amos P. K. Tai (amostai@cuhk.edu.hk), and C.-Y. Tam (francis.tam@cuhk.edu.hk)

Received: 15 September 2019 - Discussion started: 15 November 2019

Revised: 25 July 2020 - Accepted: 10 August 2020 - Published: 5 October 2020

\begin{abstract}
Surface ozone $\left(\mathrm{O}_{3}\right)$ is an important air pollutant and greenhouse gas. Land use and land cover is one of the critical factors influencing ozone, in addition to anthropogenic emissions and climate. Land use and land cover change (LULCC) can on the one hand affect ozone "biogeochemically", i.e., via dry deposition and biogenic emissions of volatile organic compounds (VOCs). LULCC can on the other hand alter regional- to large-scale climate through modifying albedo and evapotranspiration, which can lead to changes in surface temperature, hydrometeorology, and atmospheric circulation that can ultimately impact ozone "biogeophysically". Such biogeophysical effects of LULCC on ozone are largely understudied. This study investigates the individual and combined biogeophysical and biogeochemical effects of LULCC on ozone and explicitly examines the critical pathway for how LULCC impacts ozone pollution. A global coupled atmosphere-chemistry-land model is driven by projected LULCC from the present day (2000) to the future (2050) under RCP4.5 and RCP8.5 scenarios, focusing on the boreal summer. Results reveal that when considering biogeochemical effects only, surface ozone is predicted to have slight changes by up to 2 ppbv maximum in some ar-
\end{abstract}

eas due to LULCC. It is primarily driven by changes in isoprene emission and dry deposition counteracting each other in shaping ozone. In contrast, when considering the combined effect of LULCC, ozone is more substantially altered by up to 5 ppbv over several regions in North America and Europe under RCP4.5, reflecting the importance of biogeophysical effects on ozone changes. In boreal and temperate mixed forests with intensive reforestation, enhanced net radiation and sensible heat induce a cascade of hydrometeorological feedbacks that generate warmer and drier conditions favorable for higher ozone levels. In contrast, reforestation in subtropical broadleaf forests has minimal impacts on boundary-layer meteorology and ozone air quality. Furthermore, significant ozone changes are also found in regions with only modest LULCC, which can only be explained by "remote" biogeophysical effects. A likely mechanism is that reforestation induces a circulation response, leading to reduced moisture transport and ultimately warmer and drier conditions in the surrounding regions with limited LULCC. We conclude that the biogeophysical effects of LULCC are important pathways through which LULCC influences ozone air quality both locally and in remote regions even without 
significant LULCC. Overlooking the effects of hydrometeorological changes on ozone air quality may cause underestimation of the impacts of LULCC on ozone pollution.

\section{Introduction}

Surface ozone $\left(\mathrm{O}_{3}\right)$, as a harmful air pollutant, has negative consequences for human health (Occupational and Environmental Health Team, 2006; Jerrett et al., 2009; Malley et al., 2017), decreases plant gross primary productivity (e.g., Yue and Unger 2014), and leads to substantial reductions in global crop yields (Avnery et al., 2011; Tai et al., 2014; Tian et al., 2016; Tai and Val Martin, 2017; Mills et al., 2018). It is also an important greenhouse gas, contributing to climate change (Myhre et al., 2013). Surface ozone is produced by the photooxidation of precursors including carbon monoxide $(\mathrm{CO})$, methane $\left(\mathrm{CH}_{4}\right)$, and other non-methane volatile organic compounds (NMVOCs) in the presence of nitrogen oxides $\left(\mathrm{NO}_{x}\right)$. These precursors are both generated by human activities and naturally emitted from vegetation and soils. The dominant sink of surface ozone is photochemical loss and dry deposition to the surface including vegetation mainly in the form of leaf stomatal uptake. Depending on all of these production and loss mechanisms, its concentration is highly sensitive to changes in natural and anthropogenic emissions of precursors (Wang et al., 2011), land use and land cover (Ganzeveld et al., 2010; Val Martin et al., 2015; Fu and Tai, 2015), and climate (Jacob and Winner, 2009; Fiore et al., 2012; Schnell et al., 2016). Recent studies found that decreases in anthropogenic emissions alone might not necessarily decrease ozone in some polluted regions if factors such as climatic and land cover changes act to enhance ozone and offset emission control efforts (Zhou et al., 2013; Zhang et al., 2014; Xue et al., 2014).

Land use and land cover change (LULCC) can modify ozone concentration by altering key drivers of ozone such as biogenic volatile organic compound (VOC) emissions and dry deposition (e.g., Wong et al., 2018). These can be referred to as "biogeochemical effects" of LULCC on ozone (as opposed to "biogeophysical effects", which will be discussed next) because these processes entail directly modifying the biosphere-atmosphere exchange of gases and particles that alters atmospheric composition including ozone itself. Here we limit the biogeochemical effects of LULCC on ozone to processes that influence ozone directly in a given climate, including biogenic VOC emission and the dry deposition of ozone and its precursors; climatic changes that can arise from land cover disturbances of the biogeochemical cycles are not the focus.

LULCC can modify the spatial pattern and magnitude of isoprene emission due to their strong dependence on vegetation type and leaf density (Guenther et al., 2012). For instance, Lathière et al. (2006) found as much as a $29 \%$ decrease in global isoprene emission from a scenario in which $50 \%$ tropical trees are replaced by grasses. Heald and Spracklen (2015) estimated the net effect of LULCC under future anthropogenic influences as a decrease of $12 \%-15 \%$ in annual isoprene emission globally. These changes in isoprene emission can in turn modify ozone concentration. For example, Tai et al. (2013) found that LULCC projections in the Intergovernmental Panel on Climate Change (IPCC) A1B scenario with widespread crop expansion could reduce isoprene emission by $\sim 10 \%$ globally compared with the land use and land cover at present. Such a reduction could correspondingly lead to an ozone decrease of up to $4 \mathrm{ppbv}$ in the eastern US and western Europe and an increase of up to $6 \mathrm{ppbv}$ in South and Southeast Asia, whereby the difference in the sign of responses is driven primarily by the different ozone production regimes.

Dry deposition is another key factor modulating ozone (e.g., Wesely, 1989; Val Martin et al., 2014; Lin et al., 2019). Dry deposition is the most efficient over densely vegetated regions via the stomatal uptake of ozone and its precursors, and LULCC can alter these fluxes. Kroeger et al. (2014) found that reforestation over peri-urban areas in Texas, USA, could effectively enhance dry deposition, resulting in decreases in ozone and its precursors. Fu and Tai (2015) found that LULCC driven by climate and $\mathrm{CO}_{2}$ changes could overall enhance dry deposition and decrease ozone by up to $4 \mathrm{ppbv}$ in East Asia during the past 3 decades. The drydeposition enhancement mostly arises from climate- and $\mathrm{CO}_{2}$-induced increase in leaf area index (LAI), which more than offsets the compensating effect of cropland expansion (Fu and Tai, 2015). The relative importance of isoprene emission and dry deposition, which could have counteracting effects on ozone given the same LULCC, is strongly dependent on local $\mathrm{NO}_{x}$ concentrations and vegetation type (Wong et al., 2018).

LULCC can also affect weather and climate by perturbing the biosphere-atmosphere exchange of water and energy fluxes (e.g., Betts, 2001; Bonan, 2016; Pitman et al., 2009). For example, afforestation generally cools the surface in tropical regions, where evaporative cooling generally exceeds radiative warming from reduced albedo but warms the surface in boreal forests due to the more dominant radiative warming effect (e.g., Arora and Montenegro, 2011; Lee et al., 2011; Bonan, 2008). There is little consensus on the effects of afforestation in midlatitude regions (e.g., Boisier et al., 2012; de Noblet-Ducoudré et al., 2012). Recent studies (Devaraju et al., 2015; Laguë and Swann, 2016) have identified that LULCC in midlatitude regions can modify the global energy balance, impacting cloud cover, precipitation, and the circulation pattern. Furthermore, the impacts of such surface forcing could extend into the upper troposphere, alter the large-scale circulation pattern, and consequently affect the climate in remote regions (Henderson-Sellers et al., 1993; Chase et al., 2000; Swann et al., 2012; Medvigy et al., 2013). Laguë et al. (2019) examined the climatic effects of 
individual physical components in the land surface (albedo, evaporative resistance, and surface roughness) and found that temperature responds most to changes in albedo and evaporative resistance through large-scale atmospheric feedbacks. Still, how individual land characteristics play out together and interact with each other to affect the atmospheric general circulation are not fully understood.

By and large, the impacts of LULCC on weather and climate are complex. There is high confidence that LULCC can affect regional climate and climate in remote areas as far as few hundreds of kilometers away (Jia et al., 2019). The magnitude and sign of regional climate change vary across regions depending on the magnitude of LULCC and background climatic conditions. However, on the global scale, the net changes resulting from LULCC alone are relatively small (e.g., Matthews et al., 2004; Pongratz et al., 2010; Brovkin et al., 2013; Shevliakova et al., 2013; Simmons and Matthews, 2016). Thus, sometimes climatic responses to LULCC may be difficult to distinguish from natural climate variability especially on the global scale.

The modification of the overlying meteorological environment and climate induced by LULCC and the associated exchange of momentum, heat, and moisture between the land and atmosphere can be defined as biogeophysical effects of LULCC. Such effects can further alter surface ozone on local to pan-regional scales (Jiang et al., 2008; Ganzeveld et al., 2010; Wu et al., 2012), and we shall call these and related pathways the biogeophysical effects of LULCC on ozone. In particular, a LULCC-induced increase in surface temperature could (1) accelerate peroxyacetyl nitrate (PAN) decomposition into $\mathrm{NO}_{x}$ (Jacob and Winner, 2009; Doherty et al., 2013; Pusede et al., 2015), (2) increase biogenic VOC emissions from vegetation (Guenther et al., 2012; Wang et al., 2013; Squire et al., 2014), and (3) lead to more water vapor in air that tends to increase ozone destruction (Jacob and Winner, 2009). The net effect of higher temperatures is almost always ubiquitously an enhancement of ozone levels reported from both observational (e.g., Porter et al., 2015; Pusede et al., 2015) and modeling (e.g., Shen et al., 2016; Lin et al., 2017) studies in many polluted regions. Meanwhile, any reduction in precipitation, cloud cover, and soil moisture can also enhance surface ozone because of the associated increase in solar radiation and reduced dry-deposition velocity. Figure 1 summarizes the possible biogeochemical and biogeophysical pathways through which a change in forest coverage may influence surface ozone. The relative importance of different pathways, many of which may either counteract or amplify each other, is strongly dependent on forest types.

The LULCC biogeophysical effects have thus far been largely unexplored, though biogeochemical effects of LULCC have been examined by a number of studies (Wu et al., 2012; Fu and Tai, 2015; Heald and Geddes, 2016). Only a few recent studies have implicitly included such biogeophysical effects of LULCC in their coupled land-atmosphere models when assessing the impacts of LULCC on surface

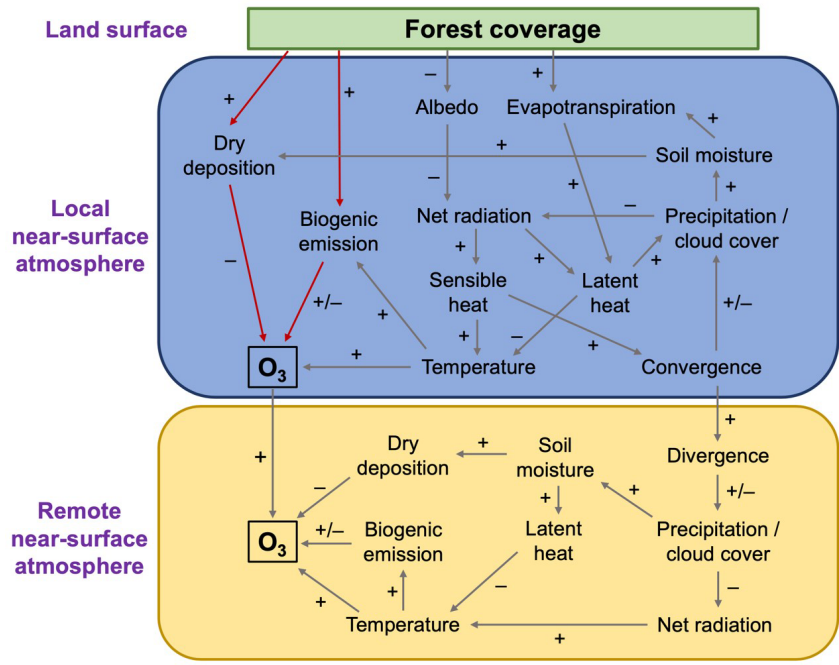

Figure 1. Schematic diagram showing the biogeochemical and biogeophysical effects of any changes in the forest cover resulting from land use and land cover change (LULCC) on surface ozone. Red arrows indicate the biogeochemical pathways and grey arrows indicate the biogeophysical effects via changes in the overlying meteorological environment. The sign associated with each arrow indicates the correlation between the two variables; the sign of the overall effect (positive or negative) of a given pathway is the product of all the signs along the pathway. We here focus on processes initiated on the land surface by LULCC and the corresponding responses in local near-surface atmosphere (blue box) and remote near-surface atmosphere (yellow box).

ozone. Val Martin et al. (2015) studied the combined effects of LULCC on surface ozone using future LULCC scenarios and found an increase of 2-3 ppbv from 2000 to 2050 over US national parks. Ganzeveld et al. (2010) also calculated the future LULCC from 2000 to 2050 and found that an increase in boundary-layer ozone mixing ratios by up to $20 \%$ over the tropics. However, these studies did not distinguish between the roles of biogeophysical vs. biogeochemical effects or decipher the physics and relative importance of various mechanisms behind the combined effects.

The aim of this study is to investigate how and to what extent global LULCC could affect surface ozone in the near future by investigating and distinguishing between the biogeochemical, biogeophysical, and combined effects of LULCC. We suggest a new line of biogeophysical pathways linking LULCC to surface ozone and also consider biogeochemical pathways through isoprene emission and dry-deposition changes caused by LULCC. In particular, over the regions without significant LULCC but showing substantial ozone changes, we find that the biogeophysical effects arising from LULCC-induced atmospheric circulation changes can be dominant and could be isolated from the combined effects. LULCC is one of the key strategies for climate change mitigation but meanwhile has substantial impacts on ozone pollution. Understanding its comprehensive pathways on surface 
ozone can help provide important references for integrated air quality and land use management in the future.

\section{Data and methods}

\subsection{Modeling framework}

To simulate the impacts of LULCC on surface ozone, we use the Community Earth System Model (CESM) version 1.2 (http://www.cesm.ucar.edu/models/, last access: 20 September 2020), which is a comprehensive global model that couples different independent components for the atmosphere, land, ocean, sea ice, land ice, and river runoff (Lamarque et al., 2012). The atmospheric component is the Community Atmosphere Model version 4 (CAM4), which uses a finitevolume dynamical core with comprehensive tropospheric and stratospheric chemistry (CAM-Chem). Chemical mechanisms are based on the Model for Ozone and Related chemical Tracers (MOZART) version 4 (Emmons et al., 2010). For the land component, the Community Land Model (CLM) version 4.5 (Oleson, 2013) considers 16 plant function types (PFTs) (Lawrence et al., 2011) and prescribes the total leaf area index (LAI), the PFT distribution, and PFT-specific seasonal LAI derived from Moderate Resolution Imaging Spectroradiometer (MODIS) observations. We use the Satellite Phenology (SP) mode of CLM4.5 for all simulations, which prescribes vegetation structural variables including LAI and canopy height; active biogeochemical cycling in terrestrial ecosystems is not turned on.

In CLM4.5, biogenic VOC emissions are computed using the Model of Emissions of Gases and Aerosols from Nature (MEGAN) version 2.1 (Guenther et al., 2012), accounting for the major known processes controlling biogenic VOC emissions from terrestrial ecosystems, such as effects of temperature, solar radiation, soil moisture, leaf age, $\mathrm{CO}_{2}$ concentrations, and vegetation species and density. Biogenic VOC emissions in MEGAN are allowed to respond interactively to changes of these processes. Thus, isoprene emission is allowed to respond to spatiotemporal changes in PFTs and the associated changes in meteorological conditions in this study. Dry deposition of gases and aerosols is computed based on the multiple-resistance approach of Wesely (1989), updated by Emmons et al. (2010), Lamarque et al. (2012), and Val Martin et al. (2014). In the scheme, dry-deposition velocity is the inverse of aerodynamic resistance (Ra), sublayer resistance $(\mathrm{Rb})$, and bulk surface resistance $(\mathrm{Rc})$, whereby Rc includes a combination of resistances from vegetation (including stomatal resistance), lower canopy, and ground with specific values for different land types. Correspondingly, dry-deposition velocity in the scheme responds to primarily meteorological and ecophysiological conditions. Soil $\mathrm{NO}_{x}$ emissions are dependent on soil moisture, soil temperature, and vegetation cover (Emmons et al., 2010; Yienger and Levy, 1995), while biomass burning emissions and an- thropogenic emissions of ozone precursors are prescribed by inventory at present-day levels.

The coupled CAM-Chem-CLM model configuration of CESM can be run with prescribed meteorology to drive atmospheric-chemistry-only simulations (hereafter as dynamical Off-line mode) or with interactive, dynamically simulated meteorology using CAM4 (hereafter as On-line mode). These two modes are both applied in the study. In particular, the Off-line mode is used to quantify the biogeochemical effects of LULCC alone on surface ozone in the absence of any associated meteorological responses to LULCC. The On-line mode is applied to assess the biogeophysical and combined effects on ozone caused by LULCC, considering also the effects of the resulting meteorological changes.

For the Off-line mode, we use the Goddard Earth Observing System Model Version 5 (GEOS-5; https://rda.ucar.edu/ datasets/ds313.0/, last access: 20 September 2020; Tilmes, 2016) assimilated meteorology as the driving fields, with a horizontal resolution of $1.9^{\circ} \times 2.5^{\circ}$ and 56 vertical levels between the surface and the $4 \mathrm{hPa}$ level. For the On-line mode of CAM-Chem-CLM, 26 vertical levels are used between the surface and $4 \mathrm{hPa}$, with the same horizontal resolution as the Off-line mode. For all simulations, concentrations of long-lived greenhouse gases including $\mathrm{CO}_{2}, \mathrm{CH}_{4}$, and $\mathrm{N}_{2} \mathrm{O}$ are prescribed at present-day levels. The anthropogenic emissions used for all simulation are described in Lamarque et al. $(2010,2012)$ and references therein. Climatic changes that may arise from land cover disturbances of the terrestrial carbon and nitrogen cycles are not the focus of this study, which aims to delineate the more immediate responses of surface ozone to LULCC.

The CAM-Chem-simulated atmospheric chemistry has been extensively evaluated and documented (e.g., Lamarque et al., 2012). In general, CAM-Chem can reasonably replicate observed values at individual sites (CASTNET for the US and EMEP for Europe; Lamarque et al., 2012; Val Martin et al., 2014; Sadiq et al., 2017) and mid- and upper-tropospheric distribution derived from a compilation of ozone measurements (Lamarque et al., 2010; Cooper et al., 2010), albeit with a general overestimation. The performance is comparable to other global and regional models (Lapina et al., 2014; Parrish et al., 2014). Uncertain emissions, coarse resolution (Lamarque et al., 2012), misrepresentation of the dry-deposition process (Val Martin et al., 2014), and overestimation of stomatal resistance (Lin et al., 2019) are all likely factors contributing to the biases.

\subsection{Present and future land use and land cover scenarios}

For the present-day land cover distribution, satellite phenology based on MODIS, and a cropping dataset from Ramankutty et al. (2008) are used (see Lawrence et al., 2011). The cropping dataset combines agricultural inventory data and two satellite-derived land products. For the future land 
cover, projections based on the Representative Concentration Pathways (RCPs) 4.5 and 8.5 scenarios are adopted (van Vuuren et al., 2011). Both are computed using integrated assessment models (IAMs) for the Phase 5 of the Coupled Model Intercomparison Project (CMIP5) community, incorporating anthropogenic transformation and activities associated with carbon releases (e.g., wood harvest). These LULCC projections are internally consistent with the corresponding emission scenarios and development pathways for the Fifth Assessment Report (AR5) of the Intergovernmental Panel on Climate Change (IPCC) (Taylor et al., 2012). In general, the RCP4.5 LULCC has the most extensive use of land management as a carbon mitigation strategy, with the expansion of forest areas combined with large reductions in croplands and grasslands. The RCP8.5 LULCC has the least effective use of land management for carbon mitigation, with a large expansion in both croplands and grasslands together with substantial forest losses. In this study, anthropogenic emissions are held constant at the present-day level for all runs; thus the effects of LULCC can be regarded as being decoupled from changes in anthropogenic emissions in order to isolate the effects of LULCC alone.

Both present-day and future land cover are transformed into PFTs changes for implementation into CESM (Lawrence et al., 2012; Oleson et al., 2013). The long-term time series of LULCC span the historical (1850-2005) and future (2006-2100) periods at 5-year intervals (Riahi et al., 2007; van Vuuren et al., 2007; Wise et al., 2009a), and are then interpolated and harmonized with smooth transitions on the annual timescale (Hurtt et al., 2011). For this work, we focus on LULCC from the present-day (2000) to the future (2050) period.

\subsection{Model experiments}

We have two sets of configuration - Off-line mode and Online mode - to investigate the impacts of LULCC on surface ozone (see Table 1). We focus on boreal summer month (June-July-August, JJA) averages as this is the period when ozone pollution is generally the most severe in the Northern Hemisphere. In the first set of simulations in Off-line mode, surface ozone would respond to LULCC only through biogeochemical effects that mainly include changes in drydeposition velocity and isoprene emissions without meteorological responses to LULCC. The Off-line mode includes a control run (Off-line_CTL) using present-day (year 2000) distribution of land use and land cover and two future simulations Off-line_45 and Off-line_85, with year-2050 land use and land cover distribution following RCP4.5 and RCP8.5, respectively. All three experiments are time-sliced simulations using prescribed GEOS-5 meteorology from 2004 to 2017 for 14 years allowing for interannual climate variability, and we use the last 10-year averages for analysis. The statistical significance of the comparison amongst these ex- periments was assessed by the Student's $t$ test at the $95 \%$ confidence levels.

In the second set of On-line mode simulations, ozone would respond to both the biogeochemical and biogeophysical effects caused by future projected LULCC. The first experiment On-line_CTL, reflects present-day conditions and uses land surface forcing for the year 2000. The second and third experiments, On-line_45TS and On-line_85TS, are time-sliced simulations using 2050 land cover distribution following RCP4.5 and RCP8.5, respectively. These two experiments are designed for direct, parallel comparison with the Off-line simulations, except with longer integration (60 years) and analysis (30 years) time to capture interannual climate variability. Because these multi-year simulations are looped over the same year of land cover forcing, they can be regarded as a quasi-ensemble run and the multi-year average can be regarded as the ensemble average. The fourth and fifth experiments, referred to as On-line_45 and On-line_85, are transient simulations performed continuously from the year 2000 to 2065 using transient land cover maps projected for the RCP4.5 and RCP8.5 scenarios, respectively. These On-line transient simulations are repeated by a series of ensemble runs with slightly different initial conditions, with two ensemble members for each scenario. All the On-line experiments analysis is based on the last 30year average and the ensemble average when modeled variables have attained a quasi-steady state. Comparison between the time-sliced and transient simulations helps us ascertain the strengths of LULCC-induced climate signals.

All simulations are performed with prescribed sea surface temperature and sea-ice cover following the HadISST dataset (Rayner et al., 2003) at the year-2000 level. Longlived greenhouse gases and thus the radiative forcing from them are kept at present-day conditions (year 2000) to isolate the effects of LULCC only.

These model configurations allow us to separate and examine (1) biogeochemical effects of LULCC on surface ozone, (2) biogeophysical effects on surface ozone, and (3) the combined effects induced by LULCC on surface ozone and its precursors and dry deposition.

\section{Results}

\subsection{Projected LULCC from 2000 to 2050}

Figure 2 shows the global distribution of present-day (year 2000) PFTs and future projected changes (2000 to 2050) following RCP4.5 and RCP8.5 for three major land cover categories. The future LULCC in RCP4.5 is characterized by extensive forest expansion (Fig. $2 \mathrm{f}, \mathrm{g}$ ). Transition from the present day to 2050 in RCP4.5 highlights the global growth of forest from $71.8 \times 10^{6}$ to $74.0 \times 10^{6} \mathrm{~km}^{2}$, at the expense of croplands (from $14.7 \times 10^{6}$ to $12.3 \times 10^{6} \mathrm{~km}^{2}$ ); grasslands slightly increase in area from $33.7 \times 10^{6}$ to $33.8 \times 10^{6} \mathrm{~km}^{2}$. 
Table 1. List of model experiments.

\begin{tabular}{|c|c|c|c|c|c|}
\hline \multicolumn{2}{|c|}{ Case name } & \multirow{2}{*}{$\begin{array}{l}\text { Land treatment } \\
\text { Present-day (2000) } \\
\text { land use and land } \\
\text { cover (LULC) map }\end{array}$} & \multirow{2}{*}{$\begin{array}{l}\text { Meteorology } \\
\text { GEOS-5 reanalysis } \\
(2004-2017)\end{array}$} & \multirow{2}{*}{$\begin{array}{l}\text { Simulated years } \\
14 \text { years, the last } 10 \\
\text { years for analysis }\end{array}$} & \multirow{2}{*}{$\begin{array}{l}\text { Model forcing } \\
\text { - Present-day (2000) well- } \\
\text { mixed greenhouse gases } \\
\text { and short-lived gases and } \\
\text { aerosols, anthropogenic } \\
\text { emissions; }\end{array}$} \\
\hline 1 & Off-line_CTL & & & & \\
\hline 2 & Off-line_45 & $\begin{array}{l}2050 \text { RCP4.5 future } \\
\text { LULC map as a time } \\
\text { slice }\end{array}$ & Same as above & Same as above & $\begin{array}{l}\text { - Present-day (2000) } \\
\text { monthly mean sea surface } \\
\text { temperature and sea ice }\end{array}$ \\
\hline 3 & Off-line_85 & $\begin{array}{l}2050 \text { RCP8.5 future } \\
\text { LULC map as a time } \\
\text { slice }\end{array}$ & Same as above & Same as above & $\begin{array}{l}\text { - All simulations use the } \\
\text { SP mode in CLM }\end{array}$ \\
\hline 4 & On-line_CTL & $\begin{array}{l}\text { Present-day (2000) } \\
\text { LULC map }\end{array}$ & Simulated online & $\begin{array}{l}60 \text { years (looped over } \\
\text { same year of forcing), } \\
\text { the last } 30 \text { years for } \\
\text { analysis }\end{array}$ & $\begin{array}{l}\text { - Isoprene emission is from } \\
\text { MEGAN }\end{array}$ \\
\hline 5 & On-line_45TS & $\begin{array}{l}2050 \text { RCP } 4.5 \text { future } \\
\text { LULC map as a time } \\
\text { slice }\end{array}$ & Same as above & Same as above & $\begin{array}{l}\text { - Dry-deposition velocity } \\
\text { is based on Wesely (1989) } \\
\text { updated by Val Martin et } \\
\text { al. (2014) }\end{array}$ \\
\hline 6 & On-line_85TS & $\begin{array}{l}2050 \text { RCP8.5 future } \\
\text { LULC map as a time } \\
\text { slice }\end{array}$ & Same as above & Same as above & \\
\hline 7,8 & On-line_45 & $\begin{array}{l}\text { 2000-2005 historical, } \\
\text { 2006-2065 RCP4.5 } \\
\text { transient LULC map }\end{array}$ & Same as above & $\begin{array}{l}66 \text { years (transient land } \\
\text { forcing all the way), } \\
\text { the last } 30 \text { years }^{\mathrm{c}} \text { for } \\
\text { analysis }\end{array}$ & \\
\hline 9,10 & On-line_85 ${ }^{\mathrm{b}}$ & $\begin{array}{l}\text { 2000-2005 historical, } \\
\text { 2006-2065 RCP8.5 } \\
\text { transient LULC map }\end{array}$ & Same as above & Same as above & \\
\hline
\end{tabular}

The net increase of $2.2 \times 10^{6} \mathrm{~km}^{2}$ of forests is consistent with that provided by Hurtt et al. (2011), Lawrence et al. (2012) and Heald and Geddes (2016). Figure $2 \mathrm{f}$ also illustrates cropland area increases over Southeast Asia, India, and China. Such increases are due to more bioenergy crop production for the purpose of climate change mitigation, economic advantages from agriculture productivity growth, lower regional land prices, and availability of undeveloped lands in these developing regions (Wise et al., 2009b; Thomson et al., 2011). In contrast, regions such as Europe, the US, and Canada undergo extensive reforestation. RCP8.5 LULCC is characterized by extensive cropland expansion (Fig. 2k, 1, m), driven mainly by a large increase in the global population and a slow increase in crop yields due to a slow rate of exchange of technology globally (Riahi et al., 2011). Cropland expansion occurs largely over the tropical belt $\left(30^{\circ} \mathrm{N}-30^{\circ} \mathrm{S}\right)$ at the ex- pense of forest reduction. The total increases in croplands are by $1.8 \times 10^{6} \mathrm{~km}^{2}$, and forest area decreases by $2.5 \times 10^{6} \mathrm{~km}^{2}$.

The present-day LAI and its changes associated with the future projected LULCC are shown in Fig. 2d, i, and n. Forest expansion leads to increases in LAI, whereas deforestation results in LAI reduction. For RCP4.5, due to the widespread reforestation and afforestation except in East Asia, LAI increases significantly. Particularly over Europe and the US, the absolute increase in LAI is $>0.1$. For RCP8.5, LAI generally declines with intense reductions over the tropical regions.

\subsection{Biogeochemical effects of LULCC on surface ozone}

Figure 3 shows the simulated changes in ozone concentrations, isoprene emission rates, and dry-deposition velocities based on the Off-line simulations. We find that isoprene 
Present-day conditions

(a) Crop

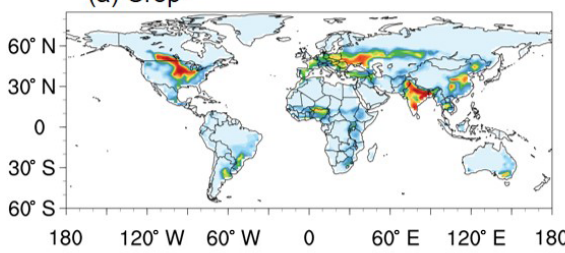

(b) Forest

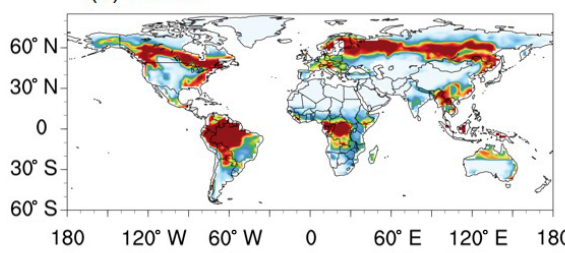

(c) Grass

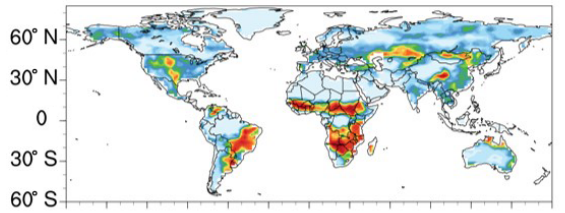

$60^{\circ} \mathrm{S}, 120^{\circ} \mathrm{W} \quad 60^{\circ} \mathrm{W}$

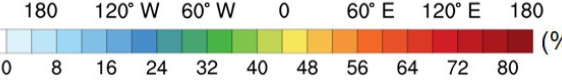

(d) LAI

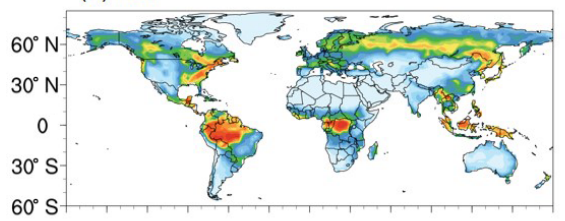

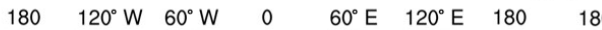
$\begin{array}{llllllllllll}0 & 0.6 & 1.2 & 1.8 & 2.4 & 3 & 3.6 & 4.2 & 4.8 & 5.4 & 6\end{array}\left(\mathrm{~m}^{2} \mathrm{~m}^{-2}\right)$

(e) Vegetation height

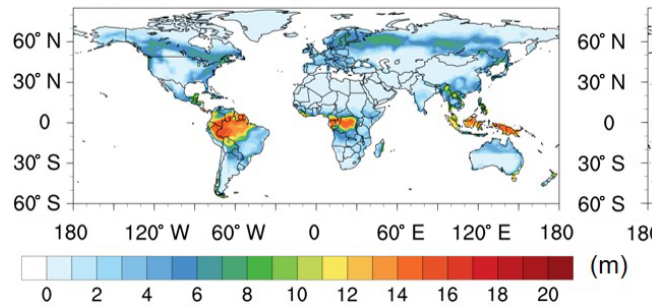

RCP4.5 projected 2050 LULCC

(f) Crop

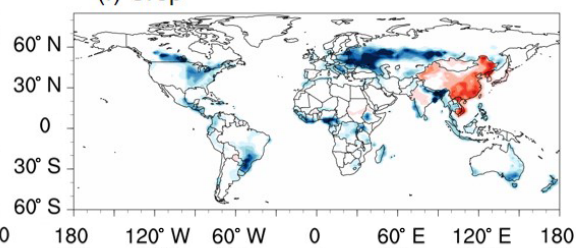

(g) Forest

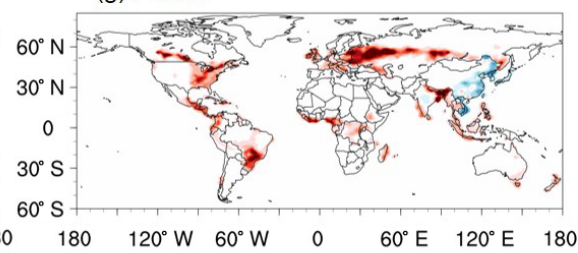

(h) Grass

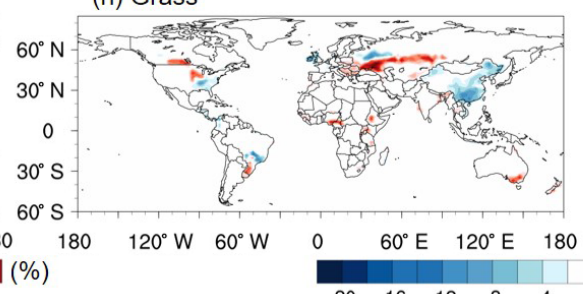

RCP8.5 projected 2050 LULCC

(k) Crop

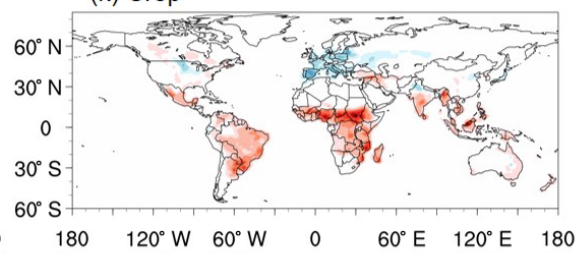

(I) Forest

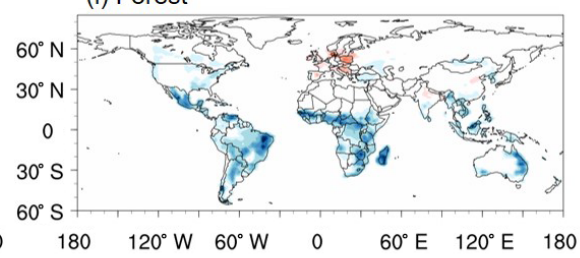

(m) Grass

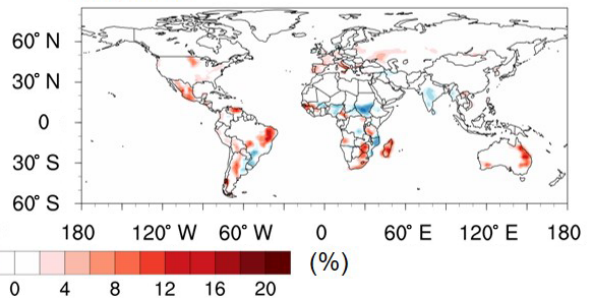

(i) LAI

(n) LAl
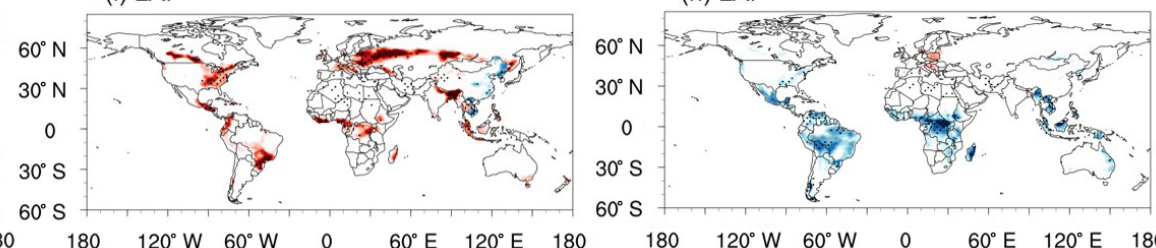

$60^{\circ} \mathrm{S}$

$0.20 .16-0.12-0.08-0.04 \quad 0.04 \quad 0.080 .120 .16 \quad 0.2\left(m^{2} \mathrm{~m}^{-2}\right)$

(j) Vegetation height

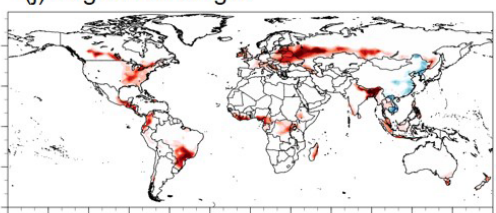

(o) Vegetation height

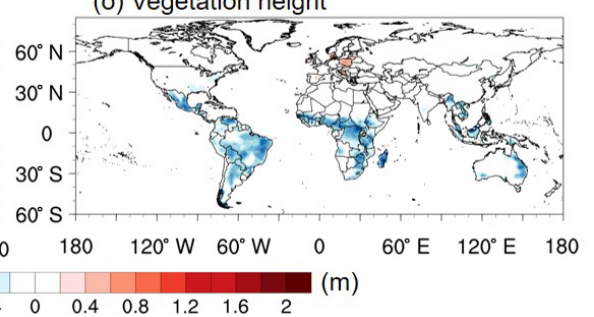

Figure 2. The present-day (2000) land use and land cover by percentage of land coverage, total leaf area index (LAI), and vegetation height (a-e) and their changes from 2000 to 2050 under RCP4.5 (f-j) and RCP8.5 (k-o) scenarios for the boreal summer (June-JulyAugust) (units at the right side of the color bar). Plant function types (PFTs) in CESM are here grouped into three major categories: crop, forest, and grass. The treatment of vegetation including PFT fractional coverage, LAI, and vegetation height is prescribed using the SP mode of CLM4.5 in both the present-day case and future LULCC scenarios. For the future cases, PFT fractional coverage is derived according to the RCP land scenarios.

emission changes correspond closely with the LULCC in each future scenario from 2000 to 2050 (Fig. 3b, e). For $\mathrm{RCP} 4.5$, isoprene emission increases over the regions with forest expansion, including the US, Europe, and some tropical regions but decreases over East Asia. Such isoprene emission increases are primarily driven by forest expansion, since forest PFTs typically emit much more isoprene than crops and grasses (Guenther et al., 2012). For RCP8.5, isoprene emission decreases over the tropics with slight increases over Europe, north China, and north India, largely due to forest reduction in this scenario.

Table 2 summarizes the percentage and absolute changes of the annual global isoprene emission. The simulated present-day annual global isoprene is $353.8 \mathrm{TgC}^{-1}$, in 
RCP4.5 projected 2050 LULCC

(a) Surface $\mathrm{O}_{3}$ concentration (ppbv)

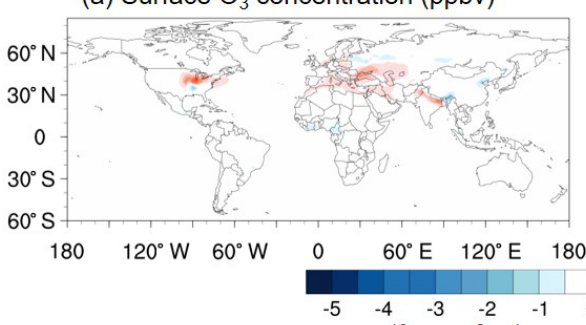

(b) Isoprene emission $\left(10^{-10} \mathrm{~kg} \mathrm{~m}^{-2} \mathrm{~s}^{-1}\right)$

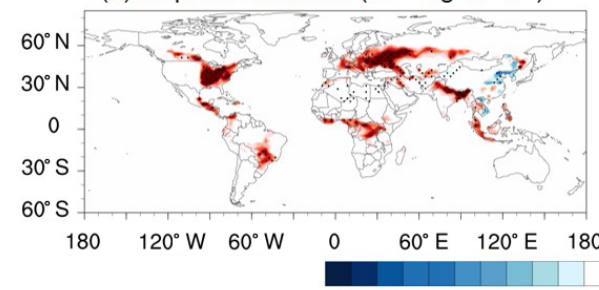

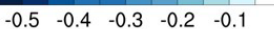

(c) Dry-deposition velocity $\left(\mathrm{cm} \mathrm{s}^{-1}\right)$

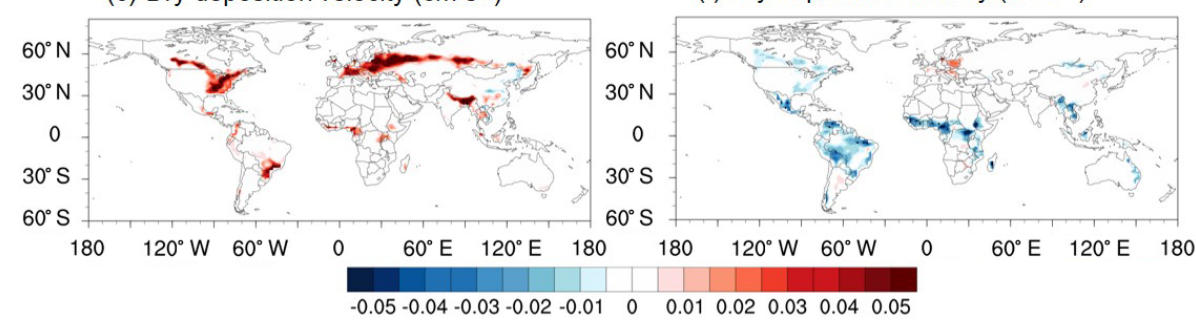

RCP8.5 projected 2050 LULCC

(d) Surface $\mathrm{O}_{3}$ concentration (ppbv)

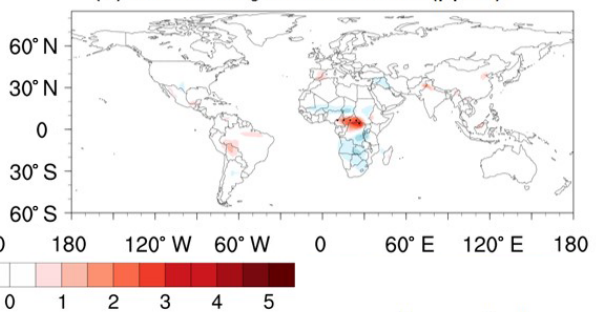

(e) Isoprene emission $\left(10^{-10} \mathrm{~kg} \mathrm{~m}^{-2} \mathrm{~s}^{-1}\right)$

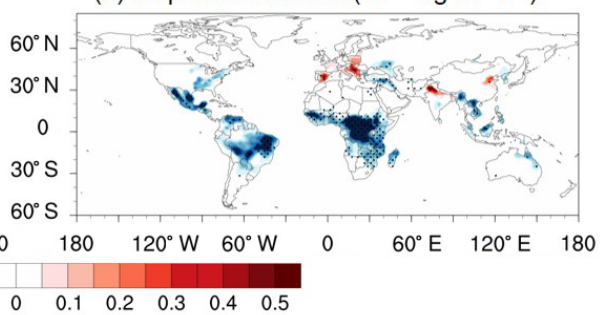

(f) Dry-deposition velocity $\left(\mathrm{cm} \mathrm{s}^{-1}\right)$

Figure 3. Simulated 2000-to-2050 changes in surface ozone, isoprene emission, and dry-deposition velocity under RCP4.5 and RCP8.5 projected LULCC for the boreal summer (June-July-August) averaged for the final 10 years of simulations. Regions with dots indicate changes that are significant at the $95 \%$ confidence level. These are results from Off-line runs with prescribed meteorology; i.e., meteorological variables do not respond to LULCC.

Table 2. Annual average global isoprene emission and ozone dry-depositional sink as influenced by future LULCC in the RCP4.5 and RCP8.5 scenarios; shown separately are changes in prescribed meteorology (biogeochemical effects only) and coupled atmosphere-chemistry-land configurations (both biogeochemical and biogeophysical effects).

\begin{tabular}{llrrrrrr}
\hline & $\begin{array}{r}\text { Isoprene } \\
\text { emissions } \\
\left(\mathrm{Tg} \mathrm{C} \mathrm{yr}^{-1}\right)\end{array}$ & $\begin{array}{r}\% \\
\text { change }\end{array}$ & $\begin{array}{r}\text { Ozone dry } \\
\text { depositional } \\
\text { sink }\left(\mathrm{Tg} \mathrm{yr}^{-1}\right)\end{array}$ & $\begin{array}{r}\% \\
\text { change }\end{array}$ & $\begin{array}{r}\text { Ozone } \\
\text { concentration } \\
\text { (ppbv) }\end{array}$ & $\begin{array}{r}\% \\
\text { change }\end{array}$ \\
\hline Off-line & Off-line_CTL & 353.8 & & 886.8 & & 23.6 & \\
& Off-line_45 & 372.3 & 5.2 & 895.4 & 1.0 & 23.7 & 0.4 \\
& Off-line_85 & 311.9 & -11.8 & 879.8 & -0.8 & 23.5 & -0.4 \\
\hline \multirow{2}{*}{ On-line } & On-line_CTL & 417.7 & & 969.2 & & 26.2 & \\
& On-line_45TS & 435.4 & 4.3 & 974.7 & 0.6 & 26.5 & 1.2 \\
& On-line_85TS & 386.8 & -7.4 & 964.1 & -0.5 & 26.4 & 0.8 \\
& On-line_45 & 440.3 & 5.5 & 975.6 & 0.6 & 26.6 & 1.5 \\
& On-line_85 & 385.2 & -7.7 & 964.1 & -0.5 & 26.3 & 0.4 \\
\hline
\end{tabular}

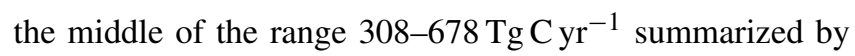
Guenther et al. (2012). For the RCP4.5 LULCC, the annual global isoprene emission increases by $5.2 \%$, but it decreases by $11.8 \%$ for RCP8.5. The isoprene emission changes are in line with these studies by Heald et al. (2008) and Wu et al. (2012), who estimated a decrease of $12 \%-15 \%$ in global isoprene emission under the net biogeochemical effect of future LULCC (A1B and A2 scenarios).

Figure $3 c$ shows that LULCC in the RCP4.5 scenario has enhanced dry-deposition velocity over most regions where forests have expanded. Forest with both large LAI and high surface roughness often provides the highest dry-deposition 
velocity amongst all PFTs (Emmons et al., 2010; Lamarque et al., 2012). The most dramatic changes occur in Europe where local maximum changes occur in land cover between forests and croplands. Local decreases over East Asia are the result of deforestation. For RCP8.5, dry-deposition velocity decreases mostly over the regions where tropical forests are replaced by croplands (Fig. 3f). Equatorial Africa and the Amazon experience the largest decrease in dry-deposition velocity relative to present-day conditions. Some increases over western Europe are the result of local reforestation.

The globally averaged change in the dry-depositional sink is around $1 \%$ (Table 2). Local dry-deposition velocity changes within $0.05 \mathrm{~cm} \mathrm{~s}^{-1}$. The value of dry-deposition velocity change is in line with previous studies exploring future 2050 LULCC alone in the dry-deposition velocity of ozone (e.g., Verbeke et al., 2015), though our results show slightly larger changes due to larger LAI differences between forests and crops/grasses during the boreal summer compared with their annual mean values of differences from Verbeke et al. (2015).

Figure $3 \mathrm{a}$ and $\mathrm{d}$ show the impacts of future projected LULCC on surface ozone. LULCC under RCP4.5 with massive forest expansion increases isoprene emission that could increase surface ozone but also enhance dry-deposition velocity that could reduce surface ozone. The overall changes in surface ozone are thus generally small due to these compensating effects. There are a few regions with surface ozone changes by up to 2 ppbv. In particular, over the US, opposite surface ozone changes are seen in RCP4.5: an increase in the northeast US and a decrease in the southeast US despite of the fact that both changes are driven by forest expansion (Fig. 3a). Such a contrasting pattern is shaped by the local atmospheric chemical conditions related to $\mathrm{O}_{3}-\mathrm{NO}_{x}-\mathrm{VOC}$ chemistry. The northeast US is a high- $\mathrm{NO}_{x}$ region, and increases in isoprene emission result in enhanced ozone, more than offsetting the effect of increasing dry-deposition velocity. In contrast, the southeast US is a high-isoprene-emitting region; additional isoprene may react with ozone and $\mathrm{NO}_{x}$, thereby suppressing surface ozone production (Kang et al., 2003; von Kuhlmann et al., 2004; Fiore et al., 2005; Pfister et al., 2008). Furthermore, in the low- $\mathrm{NO}_{x}$ region, $\mathrm{OH}$ is largely removed by reactions with biogenic VOCs, producing peroxy radicals that form $\mathrm{HO}_{2}$ or producing organic peroxides. Recent studies found that these peroxides can be rapidly photolyzed, making them at best a temporary $\mathrm{HO}_{x}$ reservoir (e.g., Thornton et al., 2002; Kubistin et al., 2010). This result implies that in low- $\mathrm{NO}_{x}$ regions ozone production may be $\mathrm{NO}_{x}$-saturated more often than current models suggest. Suppressed ozone is also found in the tropical regions of South America and Africa (Fig. S1a in the Supplement). Together with the increase in dry-deposition velocity, overall there is a decrease in surface ozone. Similar to the northeastern US conditions, southern Europe, northeastern India, and northern China are also high- $\mathrm{NO}_{x}$ regions.
Under the RCP8.5 scenario with substantial cropland and grassland expansion, decreases in isoprene emission and dry deposition again offset each other in controlling surface ozone in high- $\mathrm{NO}_{x}$ regions. Surface ozone concentration decreases by around 1 ppbv over the north-central and southern Africa but increases by up to 2 ppbv over equatorial Africa and central South America (Fig. 3d). In particular, the area with enhanced ozone in these regions corresponds well to reductions in isoprene emission and dry deposition together. Equatorial Africa is a high-isoprene-emitting, low$\mathrm{NO}_{x}$ region; thus decreases of isoprene emission together with reduced dry deposition would lead to enhanced ozone (Fig. S1b).

\subsection{Biogeophysical effects of LULCC on surface ozone}

Next, we examine results from the On-line simulations, which allow us to assess the impacts of LULCC on surface ozone when the overlying meteorological environment is also modified by LULCC. Figure 4 shows the simulated changes in ozone concentrations, isoprene emissions rates, dry-deposition velocities, and $2 \mathrm{~m}$ air temperature from the On-line time-sliced simulations. The simulated changes in surface ozone are in the range from -2 to +5 ppbv (Fig. $4 \mathrm{a}$, e). The magnitude of ozone changes in On-line simulations is overall larger than those in Off-line simulations (Fig. 3 and Table 2), which consider biogeochemical effects only, indicating the importance of complications from the changing meteorological environment in response to LULCC. Within the On-line simulations, more substantial responses of meteorology as well as of surface ozone to LULCC are found in RCP4.5 compared with those in RCP8.5.

In contrast to the clear, localized signals in ozone changes in response to LULCC through biogeochemical pathways, surface ozone changes are more complex when biogeophysical pathways are also involved (Fig. 4a, e). Most importantly, both local and remote ozone changes can be discerned. Such signals are not captured by the Off-line simulations in which changes only respond to LULCC locally (Fig. 3). Furthermore, changes in $2 \mathrm{~m}$ air temperature are found to be correlated well with patterns of changes in ozone (Fig. S2a, d), indicating that the biogeophysical drivers that modify meteorological conditions may play critical roles in ozone changes. Figure $4 \mathrm{~d}$ and $\mathrm{h}$ show simulated changes in $2 \mathrm{~m}$ air temperature before and after LULCC. Regional-scale temperature changes of up to $2 \mathrm{~K}$ are found. Such magnitudes of temperature anomalies induced by LULCC are in line with those from previous experiments (Lawrence et al., 2012; Brovkin et al., 2013). Over the regions where temperature increases, surface ozone increases correspondingly.

Changes in isoprene emission also correlate with temperature changes (Figs. 4b, d, f, h and S2b). Isoprene emission also increases in regions with forest expansion, reflecting not only the biogeochemical effects due to higher fractional coverage of isoprene-emitting vegetation types (Sect. 3.2) but 
RCP4.5 projected 2050 TIMESLC LULCC

(a) Surface $\mathrm{O}_{3}$ concentration (ppbv)

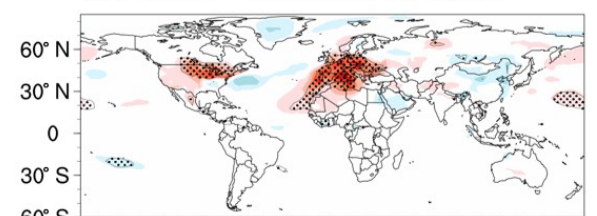

$60^{\circ} \mathrm{s}$

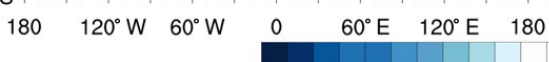

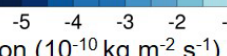

(b) Isoprene emission $\left(10^{-10} \mathrm{~kg} \mathrm{~m}^{-2} \mathrm{~s}^{-1}\right)$

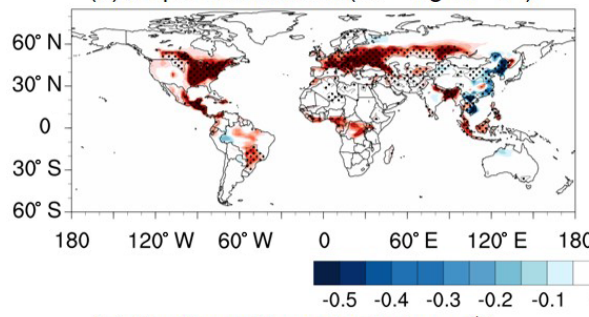

(c) Dry-deposition velocity $\left(\mathrm{cm} \mathrm{s}^{-1}\right)$

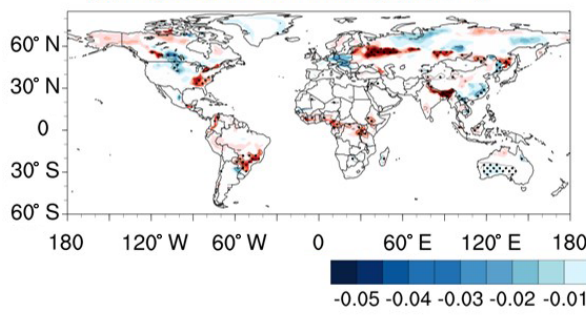

(d) $2 \mathrm{~m}$ air temperature $(\mathrm{K})$

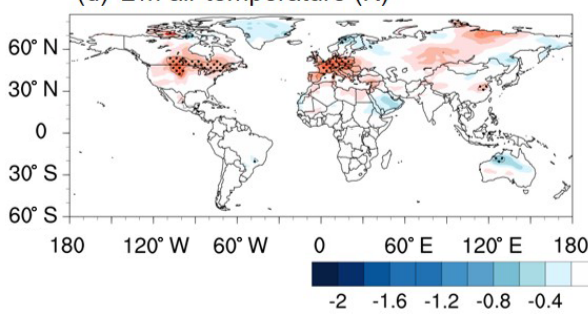

RCP8.5 projected 2050 TIMESLC LULCC

(e) Surface $\mathrm{O}_{3}$ concentration (ppbv)

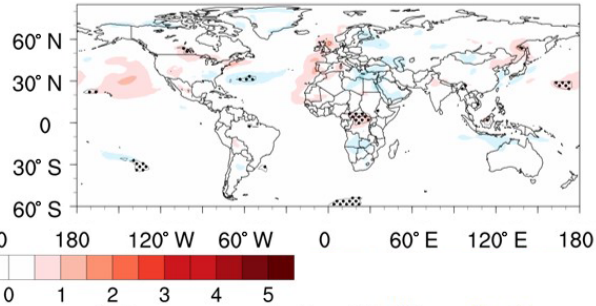

(f) Isoprene emission $\left(10^{-10} \mathrm{~kg} \mathrm{~m}^{-2} \mathrm{~s}^{-1}\right)$

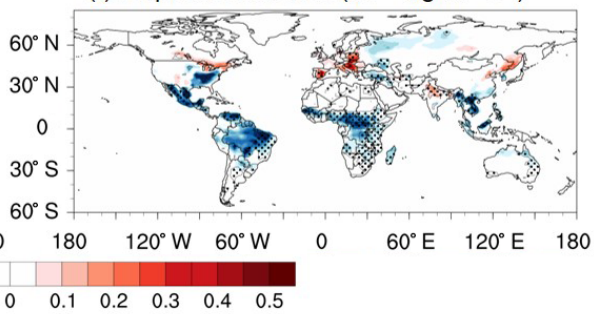

(g) Dry-deposition velocity $\left(\mathrm{cm} \mathrm{s}^{-1}\right)$

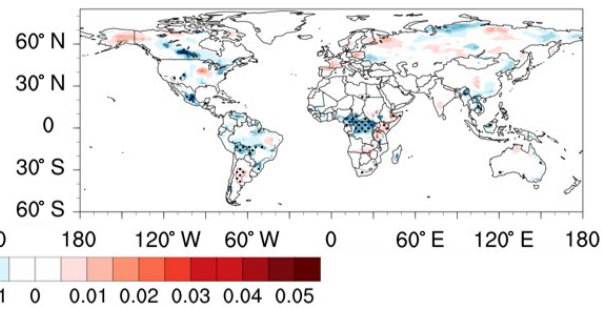

(h) $2 \mathrm{~m}$ air temperature $(\mathrm{K})$

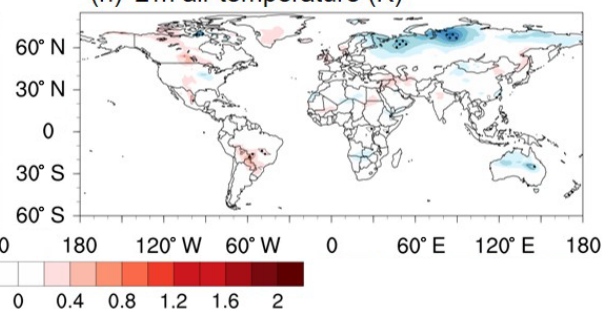

Figure 4. Simulated 2000-to-2050 changes in surface ozone, isoprene emission, dry-deposition velocity, and $2 \mathrm{~m}$ air temperature for the boreal summer averaged over the 30-year analysis window, under two future scenarios (RCP4.5 and RCP8.5) of LULCC. Regions with dots indicate changes that are significant at the $95 \%$ confidence level. These results are from the On-line runs (land forcing 2050 minus 2000 ) with dynamic meteorological responses to LULCC from time-sliced simulations On-line_45TS and On-line_85TS (Table 1).

also the biogeophysical effects arising from changing $2 \mathrm{~m}$ air temperature.

Changes in dry-deposition velocity (Figs. 4c, g and S2c) also correlate to meteorological changes. In the drydeposition scheme, stomatal resistance can respond to atmospheric dryness and soil water stress. For instance, drier conditions are captured in RCP4.5 in the north-central US as initiated by the LULCC further east, with anomalous moisture divergence (Fig. 5n) and soil moisture (Fig. 5o). The drier conditions could result in suppressed dry deposition in the corresponding regions (Fig. 5c). The responses of dry deposition to drought conditions have also been observed by recent studies (e.g., Lin et al., 2019). Furthermore, changes in surface roughness can influence aerodynamic resistance and thus dry deposition via modifying boundary-layer turbulence. In LULCC scenarios, surface roughness is modified substantially with increases in RCP4.5 (Fig. 2j) and reductions in RCP8.5 (Fig. 20), which generally decrease (increase) resistance and enhance (decrease) dry deposition in RCP4.5 (RCP8.5) in LULCC regions, though the overall changes in dry deposition are dominantly shaped by the combined meteorological effects of LULCC.

Table 2 shows that, in general, the percentage changes in isoprene emission and dry deposition in the On-line simulations are smaller than in the Off-line simulations in both scenarios, reflecting that on a global scale, LULCC-induced meteorological changes partly offset the biogeochemical effects of changing land cover types on ozone. 


\section{RCP4.5 projected 2050 TIMESLC LULCC}
(a) Surface $\mathrm{O}_{3}$ (ppbv)
(b) Isoprene emission $\left(10^{-10} \mathrm{~kg} \mathrm{~m}^{-2} \mathrm{~s}\right.$
(c) Dry-deposition velocity $\left(\mathrm{cm} \mathrm{s}^{-1}\right)$
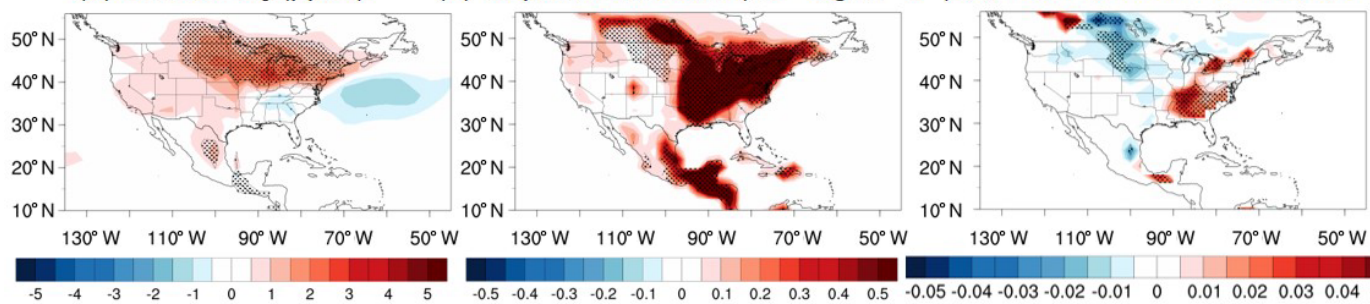

(d) Forest coverage (\%)
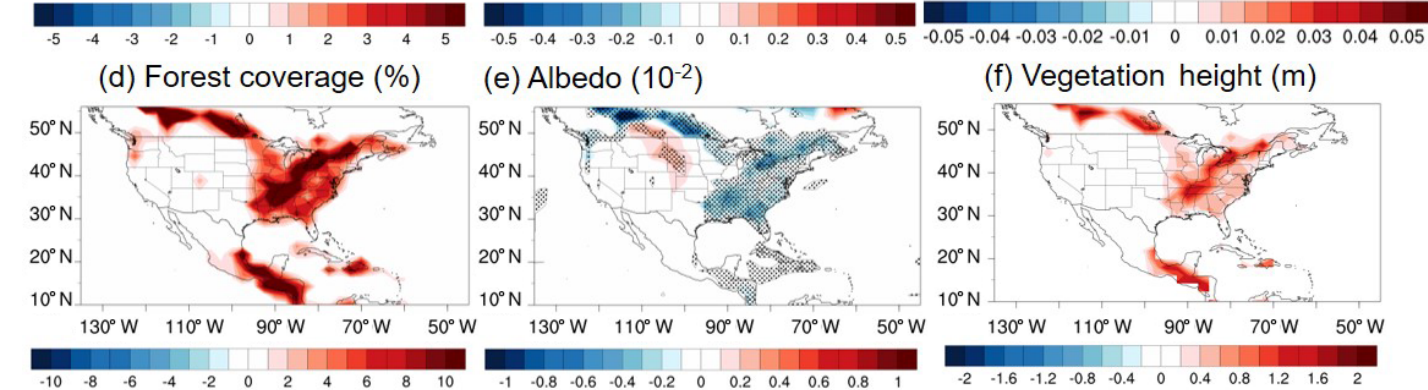

(e) Albedo $\left(10^{-2}\right)$

(f) Vegetation height $(m)$

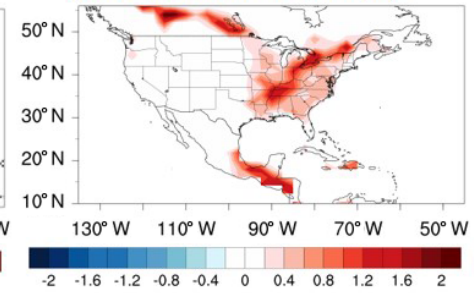

(g) Absorbed solar radiation $\left(\mathrm{W} \mathrm{m}^{-2}\right)(\mathrm{h})$ Sensible heat flux $\left(\mathrm{W} \mathrm{m}^{-2}\right)$
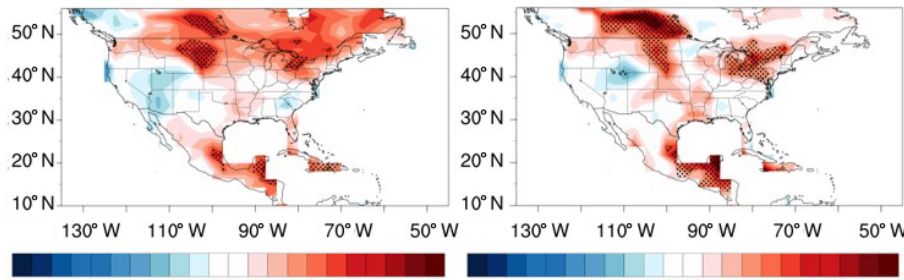

(i) Latent heat flux $\left(\mathrm{W} \mathrm{m}^{-2}\right)$

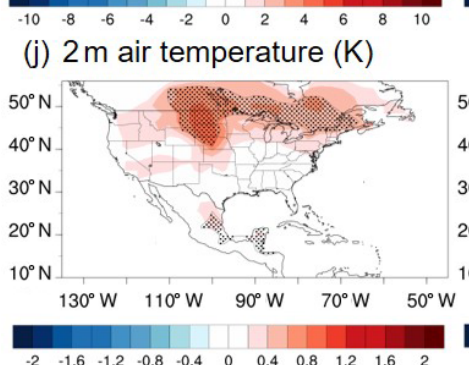

(k) Precipitation $\left(\mathrm{mm} \mathrm{day}^{-1}\right)$
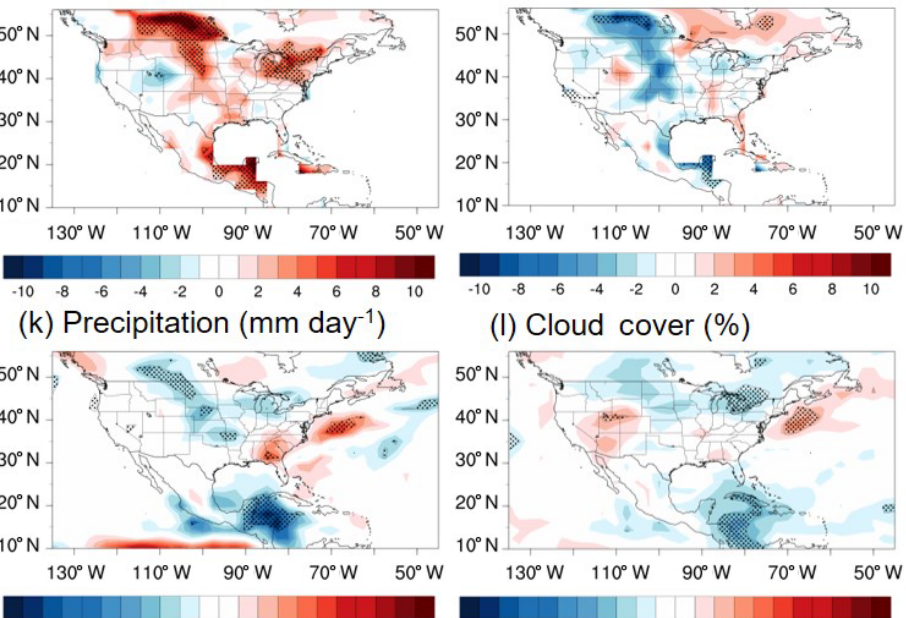

(I) Cloud cover (\%)

(m) Surface wind $\left(\mathrm{m} \mathrm{s}^{-1}\right)$

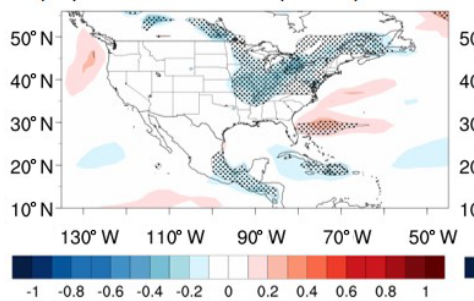

(n) Moisture transport divergence
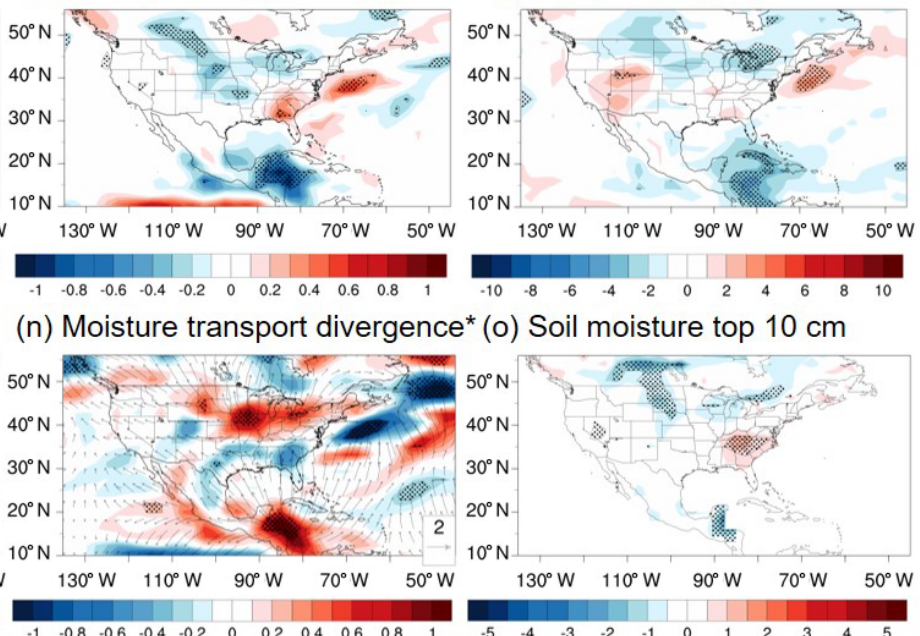

Figure 5. Changes in surface ozone, isoprene emission, dry-deposition velocity, projected forest, simulated surface albedo, vegetation height, surface net solar radiation, sensible and latent heat fluxes, $2 \mathrm{~m}$ air temperature, precipitation, cloud cover, surface wind, vertically integrated moisture transport divergence (vector: $\mathrm{kg} \mathrm{m}^{-1} \mathrm{~s}^{-1}$; shading: $10^{-5} \mathrm{~kg} \mathrm{~m}^{-2} \mathrm{~s}^{-1}$ ), and soil moisture at top $10 \mathrm{~cm}$ layer during the boreal summer over North America due to 2000-to-2050 RCP4.5 projected LULCC. Regions with dots indicate changes that are significant at the $95 \%$ confidence level.

Thus, changes in ozone can be caused by both biogeochemical and biogeophysical effects of LULCC; furthermore, both effects are highly coupled with each other. We find that in particular the biogeophysical effects of LULCC play critical roles in modulating surface ozone. Hereafter, we focus on the broad regions of North America and Europe, in order to elucidate the origins of surface ozone changes in response to LULCC-induced meteorological changes. We also focus on RCP4.5 only, because no significant changes 
in ozone or other meteorological variables are found for the RCP8.5 LULCC scenario.

\subsubsection{North America under RCP4.5 reforestation}

For RCP4.5, North America is subjected to intensive regional changes in the land cover over the eastern US and southern Canada (Fig. 5d). Significant changes in surface ozone (Fig. 4a) and $2 \mathrm{~m}$ air temperature (Fig. 4d) are found over large continuous areas in North America, including both the regions with intensive LULCC and regions where LULCC is minimal. Let us first focus on the forested regions with intensive LULCC (Fig. 5d), where reforestation results in a significant decrease in surface albedo (Fig. 5e). In the boreal and temperate mixed forests of southern Canada and northeastern US, such an albedo reduction results in a substantial enhancement in absorbed solar radiation (Fig. 5g). Typical of these forest types, the enhanced net radiation is in turn largely dissipated by higher sensible heat (Fig. 5h) instead of latent heat (Fig. 5i), resulting in a $0.5-1 \mathrm{~K}$ rise in average air temperature (Fig. 5j). This generates a warmer and drier boundary layer with suppressed precipitation (Fig. 5k), cloud cover (Fig. 51), and soil moisture (Fig. 5o), constituting a feedback that likely further enhances net radiation. All these meteorological changes contribute to higher surface ozone concentrations (Fig. 5a) beyond the biogeochemical effects alone. In southern Canada, the drier conditions even help suppress dry deposition (Fig. 5c), further enhancing ozone there. These biogeophysical effects can be summarized by the cross-amplifying pathways in the blue box in Fig. 1. Furthermore, reduced wind speed (Fig. 5m) following enhanced roughness (as represented by vegetation height in Fig. 5f) may also reduce moisture transport to these forests, inducing a greater moisture divergence there (Fig. 5n).

In contrast, in the subtropical broadleaf forests in the southeastern US, enhanced forest cover and albedo instead lead to greater moisture convergence from the Gulf of Mexico (Fig. 5n). This generates more favorable water conditions that not only dampen meteorological changes there but also promote dry deposition, leading to only slight changes in ozone. These can also be seen in the cross-counteracting pathways in the blue box of Fig. 1.

Surface ozone also increases significantly over the locations where land use does not change significantly, especially over the Midwest and Great Plains regions of the northcentral US (Fig. 5a and d). The ozone enhancement is found to correspond to the drier, warmer, and sunnier conditions there that can be regarded as "remote effects" of LULCC. Such conditions are associated with enhanced moisture divergence (Fig. 5n), which could be caused by the stronger convergence over the surrounding reforested regions that diverges moisture flow from the Great Plains, as well as reduced surface wind speed (Fig. $5 \mathrm{~m}$ ) that can influence regional moisture transport to these regions. The vertically integrated moisture fluxes at present-day conditions are shown in Fig. S3a, illustrating that normally moisture transport from the Gulf of Mexico is deflected by the Rocky Mountains and toward the eastern and north-central US. Due to reforestation, moisture transport is deflected further east and it generates an anomalous moisture flux divergence around the Midwest and Great Plains, resulting in drier conditions in these regions. The drier and warmer boundary layer is also reflected by the lower precipitation (Fig. 5k), cloud cover (Fig. 51), soil moisture (Fig. 5o), latent heat (Fig. 5i), and the associated higher net radiation (Fig. 5g), sensible heat (Fig. 5h), and air temperature (Fig. 5j). The lower soil moisture can also reduce dry deposition there (Fig. 5c). All these changes can act together to enhance surface ozone over the north-central US as remote effects of LULCC elsewhere; these pathways can be summarized by the yellow box in Fig. 1 .

\subsubsection{Europe under RCP4.5 reforestation}

Substantial increases in surface ozone (Fig. 6a) and air temperature (Fig. 6j) are found in Europe due to the RCP4.5 LULCC scenario, whereby substantial reforestation occurs over in the boreal and temperate mixed forests in the European continental regions (Fig. 6d), modifying surface energy balance significantly. Over the regions with intensive LULCC, the biogeophysical pathways shaping boundarylayer meteorology and ozone are largely similar to southern Canada and northeastern US, where the forest types are similar (see blue box in Fig. 1). In brief, reduced albedo (Fig. 6e) leads to enhanced net radiation (Fig. 6g) and sensible heat (Fig. 6h), raising $2 \mathrm{~m}$ air temperature over a large area by 0.4-1.2 K (Fig. 6j) and constituting a hydrometeorological feedback that reduces precipitation (Fig. 6k), cloud cover (Fig. 61), and soil moisture (Fig. 6o). These changes generate warmer, drier, and sunnier conditions over the forests that favor higher ozone levels. Reforestation also decreases surface wind speed (Fig. 6m) and moisture transport at the near-surface level.

The increases in surface ozone are also found to extend westward and southward beyond the regions with intensive LULCC, likely reflecting remote effects (Fig. 6a). The lower-level wind patterns at $850 \mathrm{hPa}$ under present-day conditions are shown in Fig. S3b, showing that reforested regions are originally on the southerly branch (eastern part) of the Azores High anticyclone. Circulation changes in response to reforestation appears to enable the anticyclonic system to extend eastward, allowing sunny and warm conditions typical of the Azores High to prevail over much of western Europe and parts of North Africa and enhancing surface ozone there.

Overall, we find that biogeophysical effects can have strong impacts on surface ozone through modifying local and remote meteorological conditions such as surface warming, drying, and circulation anomalies initiated by local LULCC (Fig. 1). Our results of temperature changes are consistent 


\section{RCP4.5 projected 2050 TIMESLC LULCC}

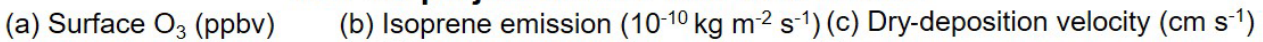
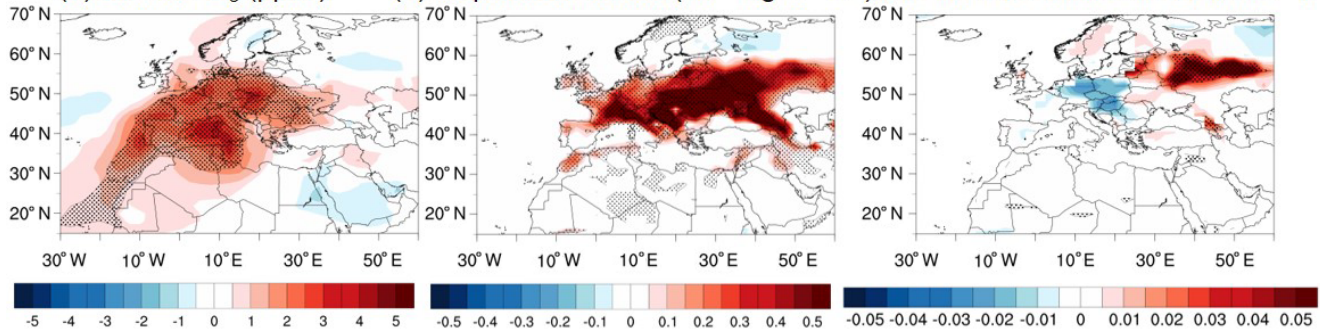

(d) Forest coverage (\%)

(e) Albedo $\left(10^{-2}\right)$

(f) Vegetation height $(\mathrm{m})$
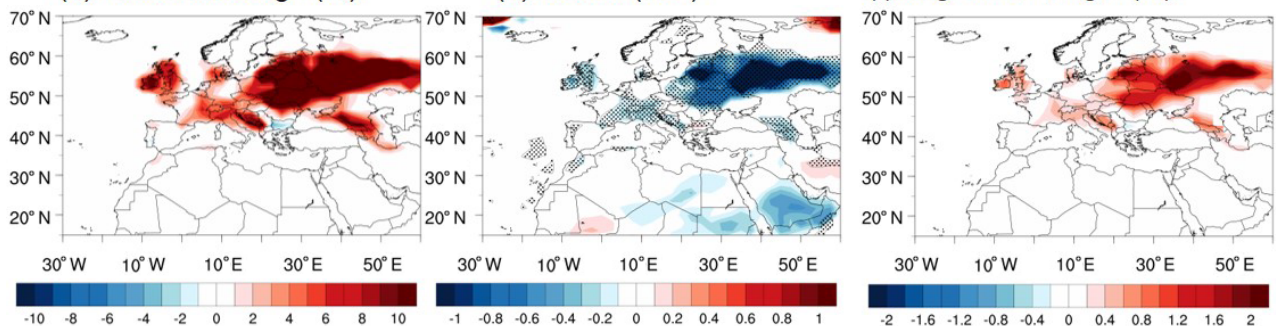

(g) Absorbed solar radiation $\left(\mathrm{W} \mathrm{m}^{-2}\right)(\mathrm{h})$ Sensible heat flux $\left(\mathrm{W} \mathrm{m}^{-2}\right)$
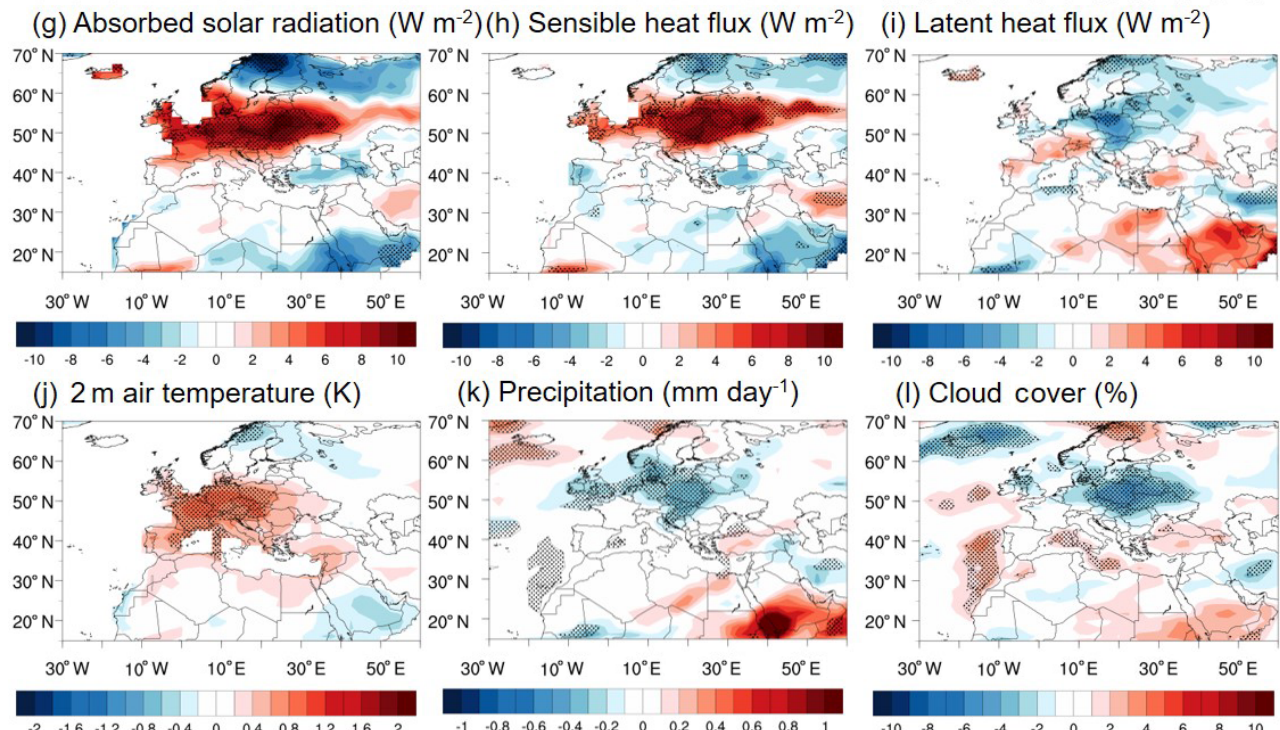

(k) Precipitation $\left(\mathrm{mm}\right.$ day $\left.^{-1}\right)$

(l) Cloud cover (\%)
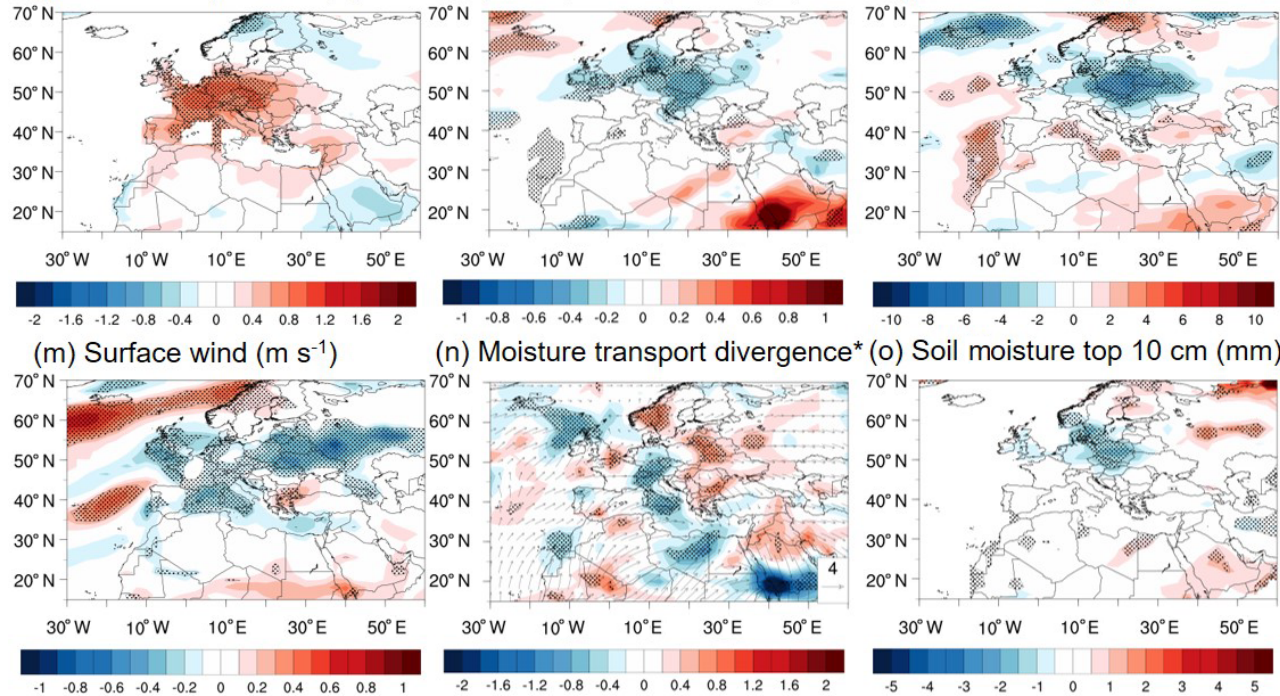

Figure 6. Similar to Fig. 5 but for Europe under RCP4.5.

with the previous study of Swann et al. (2012) that illustrated the local and remote climate effects of the northern midlatitude reforestation. They conducted a model experiment with extreme afforestation and found substantial warming in North America and Europe. In addition, Govindasamy and
Caldeira (2001) and Unger (2014) also found surface cooling due to deforestation. 


\subsubsection{Transient experiments versus time-slice experiments}

In the above sections, for a direct, parallel comparison with the Off-line configurations, we have used the time-sliced experiments with the present-day land cover in the year 2000 and future land cover in the year 2050. However, in reality the LULCC is transient with the land cover changing gradually; therefore, transient runs in On-line mode with the land cover evolving from the present day all the way to the year 2065 are also conducted (On-line_45 and On-line_85, each with two ensemble members; see Table 1). Figure 7 shows the changes in ozone and other variables from the transient simulations, using 2036 to 2065 as the 30-year averaging period to capture interannual variability. We find that changes in ozone, $2 \mathrm{~m}$ air temperature, and other factors controlling ozone are very similar between the transient and time-sliced runs (see also Table 2), with only statistically insignificant differences in different variables in most places (see Fig. S6). The consistent simulated results from the transient (Fig. 7) and timesliced (Fig. 4) LULCC further reflect the robustness of the LULCC-induced signals at least over North America and Europe, which are strong enough to cause changes in meteorology and ozone pollution in places remote from LULCC, and indicate that the atmospheric responses and biogeophysical effects are generally fast-responding at a quasi-steady state on timescales of years to decades with respect to the slow LULCC.

\section{Conclusions and discussion}

LULCC is expected to continue to co-occur with future socioeconomic development and anthropogenic emission reduction strategies. These changes likely had and will continue to have a large impact on air quality and climate. However, the impacts of LULCC on surface ozone pollution are not fully understood, and the attribution to different LULCCmediated pathways is far from complete. Here, we investigate and quantify specifically the biogeochemical effects (via modifying ozone-relevant chemical fluxes), biogeophysical effects (via modifying the overlying meteorological environment), and the combined effects of LULCC on surface ozone air quality.

We address the biogeochemical effects alone by performing CESM simulations with prescribed meteorology, and investigate the combined effects using an atmospherechemistry-land coupled configuration with dynamic meteorology. We find that the biogeochemical effects of changing isoprene emission and dry deposition following LULCC mostly offset each other, resulting in only modest changes in ozone by up to 2 ppbv from 2000 to 2050 . However, surface ozone can be significantly altered by up to 5 ppbv when considering the combined effects associated with the LULCC. In particular, the biogeophysical effects facilitated through temperature changes play a critical role in shaping surface ozone. We find that surface ozone changes correspond well with temperature changes in RCP4.5 over both regions with intensive LULCC and regions with limited LULCC.

The surface ozone changes due to future LULCC are comparable with anthropogenic emissions and climate and thus should be taken into account in future research and policy planning. For example, summertime surface ozone changes induced by climate change alone are projected to increase by 1-10 ppb in the US, Europe, and East and South Asia (e.g., Jacob and Winner, 2009; Fiore et al., 2012). It is also found that the combined effects of changing climate, emissions, and land cover on surface ozone are up to $10 \mathrm{ppb}$ in the US under two RCP scenarios, and the contributions from the three factors have comparable magnitudes although of different signs (Val Martin et al., 2015). Wang et al. (2011) found that in China, summertime surface ozone decreases by $\sim 10 \mathrm{ppb}$ on average with a maximum reduction of $25 \mathrm{ppb}$ if all anthropogenic emissions are removed. Our simulated ozone changes induced by LULCC are substantial and within the same order of magnitude as the above studies and others that considered meteorological responses to LULCC (Ganzeveld et al., 2010; Val Martin et al., 2015). This highlights the important roles of LULCC in modulating surface ozone.

The mechanisms behind hydrometeorological responses to LULCC are summarized in Fig. 1. In brief, first, surface properties and processes (e.g., surface albedo and evapotranspiration) are altered, leading to changes in the surface energy balance. In boreal and temperate mixed forests, the albedo effect dominates, leading to higher net radiation, and sensible heat and surface temperature but reduced precipitation, cloud cover, and soil moisture. These local changes can also induce a regional circulation response, in particular the formation of anomalous moisture divergence and corresponding warmer and drier conditions over the surrounding regions even with limited LULCC. In subtropical broadleaf forests, however, both the albedo and evapotranspiration effects are important, and they tend to offset each other, leading to minimal hydrometeorological changes.

In our analysis of LULCC-induced hydrometeorological changes, we have focused on the surface and the overlying boundary layer. Many studies have found that LULCCinduced surface changes can propagate to upper levels as high as $200 \mathrm{hPa}$ (e.g., Chase et al., 2000; Swann et al., 2012; Medvigy et al., 2013; Xu et al., 2015; Jia et al., 2019). In our study, significant meteorological changes can be detected at the upper levels up to $200 \mathrm{hPa}$ due to LULCC (not shown), which can lead to circulation changes, storm track displacement, and anomalous subsidence especially at midlatitudes, likely constituting feedbacks on precipitation, moisture transport, and temperature. However, we find no clear conclusions as to whether these upper-level changes and feedbacks could have sufficient influence on ozonerelevant hydrometeorological conditions beyond that or can be explained by boundary-layer dynamics alone. 
RCP4.5 projected 2050 TRANSIENT LULCC

(a) Surface $\mathrm{O}_{3}$ concentration (ppbv)

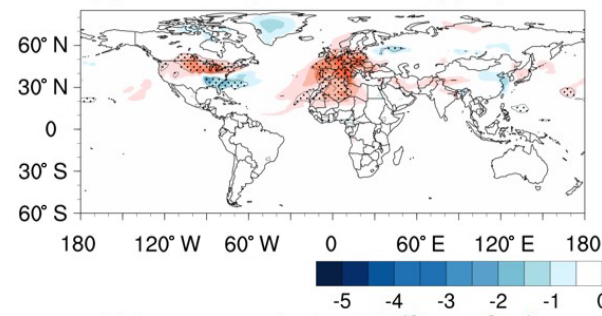

(b) Isoprene emission $\left(10^{-10} \mathrm{~kg} \mathrm{~m}^{-2} \mathrm{~s}^{-1}\right)$

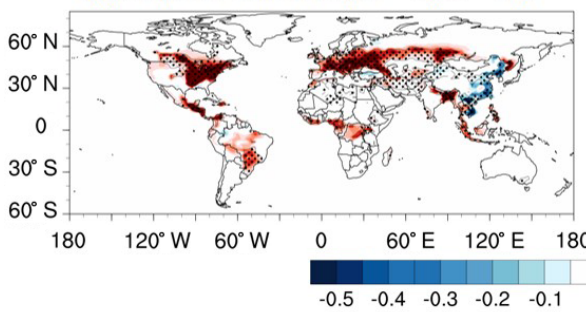

(c) Dry-deposition velocity $\left(\mathrm{cm} \mathrm{s}^{-1}\right)$

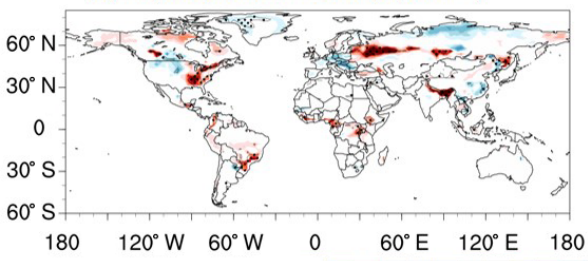

$\begin{array}{lllllllll}-0.05-0.04-0.03-0.02 & -0.01 & 0 & 0.01 & 0.02 & 0.03 & 0.04 & 0.05\end{array}$

(d) $2 \mathrm{~m}$ air temperature $(\mathrm{K})$

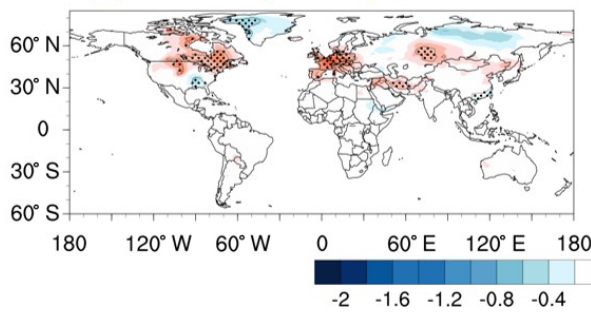

RCP8.5 projected 2050 TRANSIENT LULCC

(e) Surface $\mathrm{O}_{3}$ concentration (ppbv)

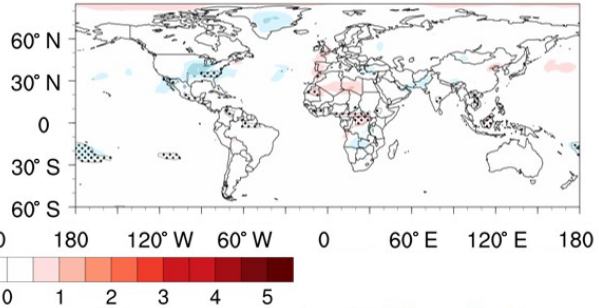

(f) Isoprene emission $\left(10^{-10} \mathrm{~kg} \mathrm{~m}^{-2} \mathrm{~s}^{-1}\right)$

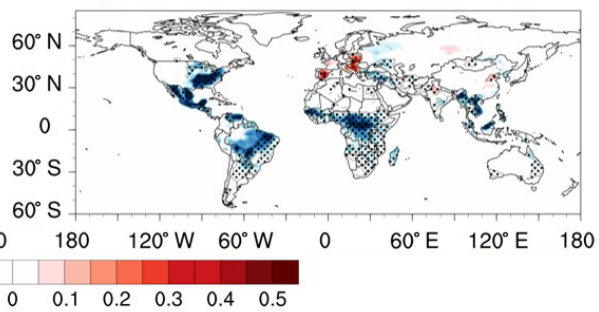

(g) Dry-deposition velocity $\left(\mathrm{cm} \mathrm{s}^{-1}\right)$

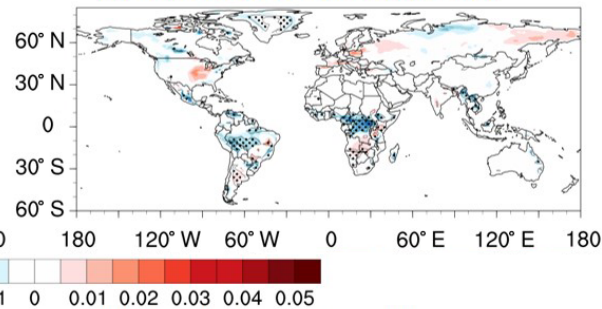

(h) $2 \mathrm{~m}$ air temperature $(\mathrm{K})$

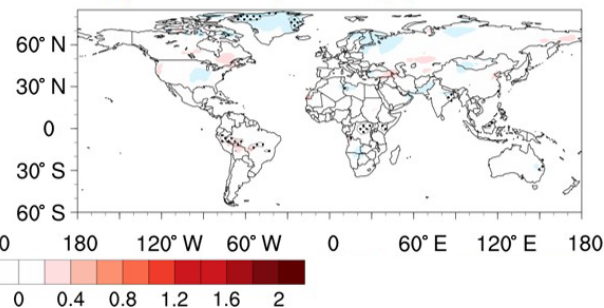

Figure 7. Similar to Fig. 4, but these results are from the transient simulations On-line_45 and On-line85 (Table 1), averaged over the two ensemble members for each scenario.

Weaker responses of temperature as well as of surface ozone to LULCC are found in RCP8.5 compared with those in RCP4.5. The different extent of temperature responses can be attributed to the location where LULCC occurs. For RCP4.5, LULCC is most intense in the midlatitude regions of the Northern Hemisphere. In contrast, most LULCC for RCP8.5 occurs over the equatorial regions and Southern Hemisphere. Temperature responses to LULCC may be less sensitive to tropical changes or changes over the Southern Hemisphere, which is dominated by the vast oceanic expanse. Van der Molen et al. (2011) using other models also found similar patterns and named such climate responses to LULCC "tropical damping". The classical theory of such tropical damping is associated with a decrease in cloud cover after deforestation, which then results in increased incoming radiation at the surface and a lower planetary albedo, both counteracting the increase in surface albedo with deforestation.

Our study has several limitations. First, the energy transport between the ocean and land has not been taken into account. Although using a fully interactive ocean component would increase the variability of simulated climate and decrease the signal-to-noise ratio in sensitivity experiments using small forcings, such as LULCC (e.g., Davin and de Noblet-Ducoudre 2010; Brovkin et al., 2013), coupled atmosphere-ocean simulations are crucial for future climate change projections for the longer term (e.g., well past the end of the 21 st century). In addition, future LULCC projections in RCPs are predicted from the ensemble of socioeconomic and emission scenarios to match identified pathways of greenhouse gas concentrations. Large uncertainties remain in such projections, calling for a more skillful de- 
sign of LULCC-related metrics and the corresponding spatial patterns for better air quality predictions. Third, the biogeochemical effects of LULCC on ozone in this study do not consider climatic changes or anthropogenic emission change but only focus on the more immediate effects generated from LULCC such as isoprene emission and dry deposition, mostly due to model limitations. For example, $\mathrm{NO}_{x}$ emission is projected to decline sharply over the northeastern US in RCP4.5. As the $\mathrm{NO}_{x}$ level decreases, ozone production may become more $\mathrm{NO}_{x}$-limited and thus the sensitivity to isoprene emission may be reduced, rendering the overall biogeochemical effects of LULCC smaller. However, since the biogeophysical effects operate in locations remote from the source regions, they may be less affected by $\mathrm{NO}_{x}$ emission changes in the source regions. The full biogeochemical effects of LULCC on ozone, which include biogeochemical-cycle-climate feedbacks and co-effects of anthropogenic emission and LULCC, will warrant further investigation but will foreseeably present greater challenges for process attribution and interpretation.

Atmospheric internal variability is one factor that could affect the significance of our results. Large internal variability of the climate system reduces the signal-to-noise ratio for LULCC-induced climatic changes (Deser et al., 2012). To ascertain the impacts of such variability, we have adopted an analysis period of 30 years for both the time-sliced simulations (looping over the single-year LULCC forcing) and two-member ensemble transient LULCC simulations. Results from both simulation approaches all show broadly consistent signals induced by LULCC in North America and Europe, indicating the significance of our results and the strong signal-to-noise ratios at least over those continents. When applicable, more ensemble members for transient simulations can be used to further confirm the impacts of such variability. Furthermore, we have compared the magnitudes of interannual standard deviations of the near-surface temperature of the CTL run with the LULCC-induced climate signals. Our results show that the climate signals are not weak and can be regionally comparable to interannual variability at midlatitudes (Fig. S4), e.g., over North America and Europe. It is also noteworthy that the time-sliced experiments with singleyear forcing looped for multiple years give results very similar to the transient simulations, further pointing to the robustness of LULCC impacts.

Our study highlights the complexity of land surface forcing and the importance of biogeophysical effects of LULCC on surface ozone air quality, emphasizing the importance of LULCC in shaping atmospheric chemistry that could be as important as anthropogenic emissions and climate. Our study can provide an important reference for policy makers to consider the substantial roles of LULCC in tackling air pollution and climate change, to develop a more comprehensive set of climatically relevant metrics for the management of the terrestrial biosphere, and to explore co-benefits among air pollution, climate change, and land use management strategies.
Data availability. Most of the data produced by this study and presented in the paper are deposited in a publicly available institutional repository, accessible via this link: https://drive.google.com/drive/folders/1ThA3S_ jOPezgU5NDKDzy-oRHwf_CpwgA?usp=sharing (Wang, 2020). Requests for raw data or the complete set of data, or any questions regarding the data, can be directed to the corresponding author, Amos P. K. Tai (amostai@ cuhk.edu.hk).

Supplement. The supplement related to this article is available online at: https://doi.org/10.5194/acp-20-11349-2020-supplement.

Author contributions. LW designed the model experiments, performed numerical simulations and analysis, and co-wrote the paper; APKT and CYT are the co-principal investigators, who designed the research, performed some of the analysis, and co-wrote the paper; MS, PW and KKWC contributed the interpretation of the results and writing of the paper.

Competing interests. The authors declare that they have no conflict of interest.

Acknowledgements. This work was supported by the ViceChancellor Discretionary Fund (Project ID: 4930744) from The Chinese University of Hong Kong (CUHK) given to the Institute of Environment, Energy and Sustainability. It is also supported by a General Research Fund grant (Project ID: 14306015) from the Research Grants Council of Hong Kong given to Amos P. K. Tai.

Financial support. This research has been supported by the ViceChancellor Discretionary Fund (Project ID: 4930744) from The Chinese University of Hong Kong (CUHK) given to the Institute of Environment, Energy and Sustainability and by a General Research Fund grant (Project ID: 14306015) from the Research Grants Council of Hong Kong.

Review statement. This paper was edited by Frank Dentener and reviewed by four anonymous referees.

\section{References}

Arora, V. K. and Montenegro, A.: Small benefits provided by realistic afforestation efforts, Nat. Geosci., 4, 514-518, https://doi.org/10.1038/ngeo1182, 2011.

Avnery S., Mauzerall D. L., Liu J., and Horowitz L. W.: Global crop yield reductions due to surface ozone exposure: 2. Year 2030 potential crop production losses and economic damage under two scenarios of $\mathrm{O}_{3}$ pollution, Atmos. Environ., 45, 22972309, https://doi.org/10.1016/j.atmosenv.2011.01.002, 2011.

Betts, R. A.: Biogeophysical impacts of land use on present-day climate: near-surface temperature change and radiative forcing, At- 
mos. Sci. Lett., 2, 39-51, https://doi.org/10.1006/asle.2001.0023, 2001.

Boisier, J. P., de Noblet-Ducoudré, N., Pitman, A. J., Cruz, F. T., Delire, C., van den Hurk, B. J. J. M., van der Molen, M. K., Müller, C., and Voldoire, A.: Attributing the impacts of land-cover changes in temperate regions on surface temperature and heat fluxes to specific causes: Results from the first LUCID set of simulations, J. Geophys. Res.-Atmos., 117, D12, https://doi.org/10.1029/2011JD017106, 2012.

Bonan, G. B.: Forests and climate change: Forcings, feedbacks, and the climate benefits of forests, Science, 320, 1444-1449, https://doi.org/10.1126/science.1155121, 2008.

Bonan, G. B.: Forests, Climate, and Public Policy: A 500Year Interdisciplinary Odyssey, Annu. Rev. Ecol. Evol. Syst., 47, 97-121, https://doi.org/10.1146/annurev-ecolsys-121415032359, 2016.

Brovkin, V., Boysen L., Arora, V. K., Boisier, J. P., Cadule, P., Chini, L., Claussen, M., Friedlingstein, P., Gayler, V., van den Hurk, B. J. J. M., Hurtt, G. C., Jones, C. D., Kato, E., de Noblet-Ducoudré, N., Pacifico, F., Pongratz, J., and Weiss, M.: Effect of anthropogenic land-use and land-cover changes on climate and land carbon storage in CMIP5 projections for the twenty-first century, J. Climate, 26, 6859-6881, https://doi.org/10.1175/JCLI-D-1200623.1, 2013.

Chase, T., Pielke, R., Kittel, T., Nemani, R., and Running, S.: Simulated Impacts of Historical Land Cover Changes on Global Climate in Northern Winter, Clim. Dynam., 16, 93-105, https://doi.org/10.1007/s003820050007, 2000.

Cooper, O. R., Parrish, D. D., Stohl, A., Trainer, M., Nédélec, P., Thouret, V., Cammas, J. P., Oltmans, S. J., Johnson, B. J., Tarasick, D., Leblanc, T., McDermid, I. S., Jaffe, D., Gao, R., Stith, J., Ryerson, T., Aikin, K., Campos, T., Weinheimer, A., and Avery, M. A.: Increasing springtime ozone mixing ratios in the free troposphere over western North America, Nature, 463, 344-348, https://doi.org/10.1038/nature08708, 2010.

de Noblet-Ducoudré, N., Boisier, J. P., Pitman, A., Bonan, G. B., Brovkin, V., Cruz, F., Delire, C., Gayler, V., van den Hurk, B. J. J. M., Lawrence, P. J., van der Molen, M. K., Müller, C., Reick, C. H., Strengers, B. J., and Voldoire, A.: Determining robust impacts of land-use-induced land cover changes on surface climate over North America and Eurasia: Results from the first set of LUCID experiments, J. Climate, 25, 3261-3281, https://doi.org/10.1175/JCLI-D-11-00338.1, 2012.

Deser, C., Knutti, R., Solomon, S., and Phillips, A.: Communication of the role of natural variability in future North American Climate, Nat. Clim. Change, 2, 775-779, https://doi.org/10.1038/nclimate1562, 2012.

Devaraju, N., Bala, G., and Modak, A.: Effects of large-scale deforestation on precipitation in the monsoon regions: Remote versus local effects, P. Natl. Acad. Sci. USA, 112, 3257-3262, https://doi.org/10.1073/pnas.1423439112, 2015.

Doherty, R. M., Wild, O., Shindell, D. T., Zeng, G., MacKenzie, I. A., Collins, W. J., Fiore, A. M., Stevenson, D. S., Dentener, F. J., Schultz M. G., Hess, P., Derwent, R. G., and Keating, T. J.: Impacts of climate change on surface ozone and intercontinental ozone pollution: A multi-model study, J. Geophys. Res.-Atmos., 118, 1-20, https://doi.org/10.1002/jgrd.50266, 2013.

Emmons, L. K., Walters, S., Hess, P. G., Lamarque, J.-F., Pfister, G. G., Fillmore, D., Granier, C., Guenther, A., Kinnison,
D., Laepple, T., Orlando, J., Tie, X., Tyndall, G., Wiedinmyer, C., Baughcum, S. L., and Kloster, S.: Description and evaluation of the Model for Ozone and Related chemical Tracers, version 4 (MOZART-4), Geosci. Model Dev., 3, 43-67, https://doi.org/10.5194/gmd-3-43-2010, 2010.

Fiore, A. M., Horowitz, L. W., Purves, D. W., Levy II, H., Evans, M. J., Wang, Y., Li, Q., and Yantosca, M.: Evaluating the contribution of changes in isoprene emissions to surface ozone trends over the eastern United States, J. Geophys. Res.-Atmos., 110, D12303, https://doi.org/10.1029/2004JD005485, 2005.

Fiore, A. M., Naik, V., Spracklen, D. V., Steiner, A., Unger, N., Prather, M., and Bergmann, D.: Global air quality and climate, Chem. Soc. Rev., 41, 6663-6683, https://doi.org/10.1039/C2CS35095E, 2012.

$\mathrm{Fu}$, Y. and Tai, A. P. K.: Impact of climate and land cover changes on tropospheric ozone air quality and public health in East Asia between 1980 and 2010, Atmos. Chem. Phys., 15, 10093-10106, https://doi.org/10.5194/acp-15-10093-2015, 2015.

Ganzeveld, L., Bouwman, L., Stehfest, E., van Vuuren, D. P., Eickhout, B., and Lelieveld, J.: Impact of future land use and land cover changes on atmospheric chemistryclimate interactions, J. Geophys. Res.-Atmos., 115, D23301, https://doi.org/10.1029/2010JD014041, 2010.

Govindasamy, B. and Caldeira, K.: Land use changes and Northern Hemisphere cooling, Geophys. Res. Lett., 28, 291-294, https://doi.org/10.1029/2000GL006121, 2001.

Guenther, A. B., Jiang, X., Heald, C. L., Sakulyanontvittaya, T., Duhl, T., Emmons, L. K., and Wang, X.: The Model of Emissions of Gases and Aerosols from Nature version 2.1 (MEGAN2.1): an extended and updated framework for modeling biogenic emissions, Geosci. Model Dev., 5, 1471-1492, https://doi.org/10.5194/gmd-5-1471-2012, 2012.

Heald, C. L. and Geddes, J. A.: The impact of historical land use change from 1850 to 2000 on secondary particulate matter and ozone, Atmos. Chem. Phys., 16, 14997-15010, https://doi.org/10.5194/acp-16-14997-2016, 2016.

Heald, C. L. and Spracklen, D. V.: Land use change impacts on air quality and climate, Chem. Rev., 115, 4476-4496, https://doi.org/10.1021/cr500446g, 2015.

Heald C. L., Henze, D. K., Horowitz, L. W., Feddema, J., Lamarque, J.-F., Guenther, A., Hess, P. G., Vitt, F., Seinfeld, J. F., Goldstein, A. H., and Fung, I.: Predicted change in global secondary organic aerosol concentrations in response to future climate, emissions, and land use change, J. Geophys. Res., 113, D05211, https://doi.org/10.1029/2007JD009092, 2008.

Henderson-Sellers, A., Dickinson, R. E., Durbidge, T. B., Kennedy, P. J., McGuffie, K., and Pitman, A. J.: Tropical deforestation: Modeling local- to regional-scale climate change, J. Geophys. Res.-Atmos., 98, 7289-7315, https://doi.org/10.1029/92JD02830, 1993.

Hurtt, G. C., Chini, L. P., Frolking, S., Betts, R. A., Feddema, J., Fischer, G., Fisk, J. P., Hibbard, K., Houghton, R. A., Janetos, A., Jones, C. D., Kindermann, G., Kinoshita, T., Goldewijk, K. K., Riahi, K., Shevliakova, E., Smith, S., Stehfest, E., Thomson, A., Thornton, P., van Vuuren, D. P., and Wang, Y. P.: Harmonization of land-use scenarios for the period 1500-2100: 600 years of global gridded annual land-use transitions, wood harvest, and resulting secondary lands, Climatic Change, 109, 117161, https://doi.org/10.1007/s10584-011-0153-2, 2011. 
Jacob, D. J. and Winner, D. A.: Effect of climate change on air quality, Atmos. Environ., 43, 51-63, https://doi.org/10.1016/j.atmosenv.2008.09.051, 2009.

Jerrett, M., Burnett, R. T., Pope, C. A., Ito, K., Thurston, G., Krewski, D., Shi, Y., Calle, E., and Thun, M.: Long-Term Ozone Exposure and Mortality, New Engl. J. Med., 360, 1085-1095, https://doi.org/10.1056/NEJMoa0803894, 2009.

Jia, G., Shevliakova, E., Artaxo, P., de Noblet-Ducoudré, N., Houghton, R., House, J., Kitajima, K., Lennard, C., Popp, A., Sirin, A., Sukumar, R., and Verchot, L.: Land-climate interactions, in: Climate Change and Land: an IPCC special report on climate change, desertification, land degradation, sustainable land management, food security, and greenhouse gas fluxes in terrestrial ecosystems, edited by: Shukla, P. R., Skea, J., Calvo Buendia, E., Masson-Delmotte, V., Pörtner, H.-O., Roberts, D. C., Zhai, P., Slade, R., Connors, S., van Diemen, R., Ferrat, M., Haughey, E., Luz, S., Neogi, S., Pathak, M., Petzold, D, Portugal Pereira, J., Vyas, P., Huntley, E., Kissick, K., Belkacemi, M., and Malley, J., in press, 2019.

Jiang, X., Wiedinmyer, C., Chen, F., Yang, Z.-L., and Lo, J. C.F.: Predicted impacts of climate and land use change on surface ozone in the Houston, Texas, area, J. Geophys. Res., 113, D20312, https://doi.org/10.1029/2008JD009820, 2008.

Kang, D., Aneja, V. P., Mathur, R., and Ray, J. D.: Nonmethane hydrocarbons and ozone in three rural southeast United States national parks: A model sensitivity analysis and comparison to measurements, J. Geophys. Res., 108, 4604, https://doi.org/10.1029/2002JD003054, 2003.

Kubistin, D., Harder, H., Martinez, M., Rudolf, M., Sander, R., Bozem, H., Eerdekens, G., Fischer, H., Gurk, C., Klüpfel, T., Königstedt, R., Parchatka, U., Schiller, C. L., Stickler, A., Taraborrelli, D., Williams, J., and Lelieveld, J.: Hydroxyl radicals in the tropical troposphere over the Suriname rainforest: comparison of measurements with the box model MECCA, Atmos. Chem. Phys., 10, 9705-9728, https://doi.org/10.5194/acp10-9705-2010, 2010.

Kroeger, T., Escobedo, F. J., Hernandez, J. L., Varela, S., Delphin, S., Fisher, J. R. B., and Waldron, J.: Reforestation as a novel abatement and compliance measure for groundlevel ozone, P. Natl. Acad. Sci. USA, 111, 4204-4213, https://doi.org/10.1073/pnas.1409785111, 2014.

Lamarque, J.-F., Bond, T. C., Eyring, V., Granier, C., Heil, A., Klimont, Z., Lee, D., Liousse, C., Mieville, A., Owen, B., Schultz, M. G., Shindell, D., Smith, S. J., Stehfest, E., Van Aardenne, J., Cooper, O. R., Kainuma, M., Mahowald, N., McConnell, J. R., Naik, V., Riahi, K., and van Vuuren, D. P.: Historical (1850-2000) gridded anthropogenic and biomass burning emissions of reactive gases and aerosols: methodology and application, Atmos. Chem. Phys., 10, 7017-7039, https://doi.org/10.5194/acp-10-7017-2010, 2010.

Lamarque, J.-F., Emmons, L. K., Hess, P. G., Kinnison, D. E., Tilmes, S., Vitt, F., Heald, C. L., Holland, E. A., Lauritzen, P. H., Neu, J., Orlando, J. J., Rasch, P. J., and Tyndall, G. K.: CAM-chem: description and evaluation of interactive atmospheric chemistry in the Community Earth System Model, Geosci. Model Dev., 5, 369-411, https://doi.org/10.5194/gmd-5369-2012, 2012.

Laguë, M. and Swann, A. S.: Progressive midlatitude afforestation: Impacts on clouds, global energy transport, and precipitation,
J. Climate, 29, 5561-5573, https://doi.org/10.1175/JCLI-D-150748.1, 2016.

Laguë, M. M., Bonan, G. B., and Swann, A. S.: Separating the impact of individual land surface properties on the terrestrial surface energy budget in both the coupled and uncoupled land-atmosphere system, J. Climate, 32, 5725-5744, https://doi.org/10.1175/JCLI-D-18-0812.1, 2019.

Lapina, K., Henze, D. K., Milford, J. B., Huang, M., Lin, M., Fiore, A. M., Carmichael, G., Pfister, G. G., and Bowman, K.: Assessment of source contributions to seasonal vegetative expo- sure to ozone in the US, J. Geophys. Res.-Atmos., 119, 324-340, https://doi.org/10.1002/2013JD020905, 2014.

Lathière, J., Hauglustaine, D. A., Friend, A. D., De NobletDucoudré, N., Viovy, N., and Folberth, G. A.: Impact of climate variability and land use changes on global biogenic volatile organic compound emissions, Atmos. Chem. Phys., 6, 2129-2146, https://doi.org/10.5194/acp-6-2129-2006, 2006.

Lawrence, D. M., Oleson, K. W., Flanner, M. G., Thornton, P. E., Swenson, S. C., Lawrence, P. J., Zeng, X., Yang, Z.-L., Levis, S., Sakaguchi, K., Bonan, G. B., and Slater, A. G.: Parameterization Improvements and Functional and Structural Advances in Version 4 of the Community Land Model, J. Adv. Model. Earth Syst., 3, M03001, https://doi.org/10.1029/2011MS00045, 2011.

Lawrence, P. J., Feddema, J. J., Bonan, G. B., Meehl, G. A., O’Neill, B. C., Levis, S., Lawrence, D. M., Oleson, K. W., Kluzek, E., Lindsay, K., and Thorton, P. E.: Simulating the Biogeochemical and Biogeophysical Impacts of Transient Land Cover Change and Wood Harvest in the Community Climate System Model (CCSM4) from 1850 to 2100, J. Climate, 25, 3071-3095, https://doi.org/10.1175/JCLI-D-11-00256.1, 2012.

Lee, X., Goulden, M. L., Hollinger, D. Y., Barr, A., Black, T. A., Bohrer, G., Bracho, R., Drake, B., Goldstein, A., Gu, L., Katul, G., Kolb, T., Law, B. E., Margolis, H., Meyers, T., Monson, R., Munger, W., Oren, R., Paw U, T. K., Richardson, A. D., Schmid, H. P., Staebler, R., Wofsy, S., and Zhao, L.: Observed increase in local cooling effect of deforestation at higher latitudes, Nature, 479, 384-387, https://doi.org/10.1038/nature10588, 2011.

Lin, M., Horowitz, L. W., Payton, R., Fiore, A. M., and Tonnesen, G.: US surface ozone trends and extremes from 1980 to 2014: quantifying the roles of rising Asian emissions, domestic controls, wildfires, and climate, Atmos. Chem. Phys., 17, 29432970, https://doi.org/10.5194/acp-17-2943-2017, 2017.

Lin, M., Malyshev, S., Shevliakova, E., Paulot, F., Horowitz, L. W., Fares, S., Mikkelsen, T. N., and Zhang, L.: Sensitivity of ozone dry deposition to ecosystem-atmosphere interactions: A critical appraisal of observations and simulations, Global Biogeochem. Cy., 33, 1264-1288, https://doi.org/10.1029/2018GB006157, 2019.

Malley, C. S., Henze, D. K., Kuylenstierna, J. C. I., Vallack, H. W., Davila, Y., Anenberg, S. C., Turner, M. C., and Ashmore, M. R.: Updated global estimates of respiratory mortality in adults $\geq 30$ years of age attributable to longterm ozone exposure, Environ. Health Perspect., 125, 087021, https://doi.org/10.1289/EHP1390, 2017.

Matthews, H. D. D., Weaver, A. J. J., Meissner, K. J. J., Gillett, N. P. P., and Eby, M.: Natural and anthropogenic climate change: incorporating historical land cover change, vegetation dynamics and the global carbon cycle, Clim. Dynam., 22, 461-479, https://doi.org/10.1007/s00382-004-0392-2, 2004. 
Medvigy, D., Walko, R., Otte, M., and Avissar, R. Simulated Changes in Northwest U.S. Climate in Response to Amazon Deforestation, J. Climate, 26, 9115-9136, https://doi.org/10.1175/JCLI-D-12-00775.1, 2013.

Myhre, G., Shindell, D., Bréon, F.-M., Collins, W., Fuglestvedt, J., Huang, J., Koch, D., Lamarque, J.-F., Lee, D., Mendoza, B., Nakajima, T., Robock, A., Stephens, G., Takemura, T., and Zhang, H.: Anthropogenic and Natural Radiative Forcing, in: Climate Change 2013: The Physical Science Basis. Contribution of Working Group I to the Fifth Assessment Report of the Intergovernmental Panel on Climate Change, edited by: Stocker, T. F., Qin, D., Plattner, G.-K., Tignor, M., Allen, S. K., Boschung, J., Nauels, A., Xia, Y., Bex, V., and Midgley, P. M., Cambridge University Press, Cambridge, UK and New York, NY, USA, 2013.

Occupational and Environmental Health Team (World Health Organization): WHO Air quality guidelines for particulate matter, ozone, nitrogen dioxide and sulfur dioxide: global update 2005: summary of risk assessment, World Health Organization, available at: https://apps.who.int/iris/handle/10665/69477 (last access: 20 September 2020), 2006.

Oleson, K. W., Lawrence D. W., and Bonan, G. B.: Technical description of version 4.5 of the Community Land Model (CLM). NCAR Technical Note NCAR/TN-503+STR, National Centre for Atmospheric Research, Boulder, USA, 2013.

Parrish, D. D., Lamarque, J. F., Naik, V., Horowitz, L., Shindell, D. T., Staehelin, J., Derwent, R., Cooper, O. R., Tanimoto, H., Volz-Thomas, A., and Gilge, S.: Long-term changes in lower tropospheric baseline ozone concentrations: Comparing chemistry-climate models and observations at northern midlatitudes, J. Geophys. Res.-Atmos., 119, 5719-5736, https://doi.org/10.1002/2013JD021435, 2014.

Pfister, G. G., Emmons, L. K., Hess, P. G., Lamarque, J.-F., Orlando, J. J., Walters, S., Guenther, A., Palmer, P. I., and Lawrence, P. J.: Contribution of isoprene to chemical budgets: A model tracer study with the NCAR CTM MOZART-4, J. Geophys. Res., 113, D05308, https://doi.org/10.1029/2007JD008948, 2008.

Pitman, A. J., de Noblet-Ducoudre, N., Cruz, F. T., Davin, E. L., Bonan, G. B., Brovkin, V., Claussen, M., Delire, C., Ganzeveld, L., Gayler, V., van den Hurk, B., Lawrence, P. J., van der Molen, M. K., Muller, C., Reick, C. H., Seneviratne, S. I., Strengers, B. J., and Voldoire, A.: Uncertainties in climate responses to past land cover change: First results from the LUCID intercomparison study, Geophys. Res. Lett., 36, L14814, https://doi.org/10.1029/2009GL039076, 2009.

Pongratz, J., Reick, C. H., Raddatz, T., and Claussen, M.: Biogeophysical versus biogeochemical climate response to historical anthropogenic land cover change. Geophys. Res. Lett., 37, 1-5, https://doi.org/10.1029/2010GL043010, 2010.

Porter, W. C., Heald, C. L., Cooley, D., and Russell, B.: Investigating the observed sensitivities of air-quality extremes to meteorological drivers via quantile regression, Atmos. Chem. Phys., 15, 10349-10366, https://doi.org/10.5194/acp-15-103492015, 2015.

Pusede, S. E., Steiner, A. L., and Cohen, R. C.: Temperature and recent trends in the chemistry of continental surface ozone, Chem. Rev., 115, 3898-3918, https://doi.org/10.1021/cr5006815, 2015.

Ramankutty, N., Evan, A. T., Monfreda, C., and Foley, J. A.: Farming the planet: 1. Geographic distribution of global agricultural lands in the year 2000, Global Biogeochem. Cy., 22, GB1003, https://doi.org/10.1029/2007GB002952, 2008.

Rayner, N. A., Parker, D. E., Horton, E. B., Folland, C. K., Alexander, L. V., Rowell, D. P., Kent, E. C., and Kaplan, A.: Global analyses of sea surface temperature, sea ice, and night marine air temperature since the late nineteenth century, J. Geophys. Res.Atmos., 108, D002670, https://doi.org/10.1029/2002JD002670, 2003.

Riahi, K., Grübler, A., and Nakicenovic, N.: Scenarios of longterm socio-economic and environmental development under climate stabilization, Technol. Forecast. Soc. Change, 74, 887-935, https://doi.org/10.1016/j.techfore.2006.05.026, 2007.

Riahi, K., Krey, V., Rao, S., Chirkov, V., Fischer, G., Kolp, P., Kindermann, G., Nakicenovic, N., and Rafai, P.: RCP8.5-exploring the consequence of high emission trajectories, Climatic Change, 109, 33, https://doi.org/10.1007/s10584-011-0149-y, 2011.

Sadiq, M., Tai, A. P. K., Lombardozzi, D., and Val Martin, M.: Effects of ozone-vegetation coupling on surface ozone air quality via biogeochemical and meteorological feedbacks, Atmos. Chem. Phys., 17, 3055-3066, https://doi.org/10.5194/acp-173055-2017, 2017.

Schnell, J. L., Prather, M. J., Josse, B., Naik, V., Horowitz, L. W., Zeng, G., Shindell, D. T., and Faluvegi, G.: Effect of climate change on surface ozone over North America, Europe, and East Asia, Geophys. Res. Lett., 43, 3509-3518, https://doi.org/10.1002/2016GL068060, 2016.

Shen, L., Mickley, L. J., and Gilleland, E.: Impact of increasing heat waves on US ozone episodes in the 2050s: Results from a multimodel analysis using extreme value theory, Geophys. Res. Lett., 43, 4017-4025, https://doi.org/10.1002/2016GL068432, 2016.

Shevliakova, E., Stouffer, R. J., Malyshev, S., Krasting, J. P., Hurtt, G. C., and Pacala, S. W. : Historical warming reduced due to enhanced land carbon uptake, P. Natl. Acad. Sci. USA, 110, 1673016735, https://doi.org/10.1073/pnas.1314047110, 2013.

Simmons, C. T. and Matthews, H. D.: Assessing the implications of human land-use change for the transient climate response to cumulative carbon emissions, Environ. Res. Lett., 11, 035001, https://doi.org/10.1088/1748-9326/11/3/035001, 2016.

Squire, O. J., Archibald, A. T., Abraham, N. L., Beerling, D. J., Hewitt, C. N., Lathière, J., Pike, R. C., Telford, P. J., and Pyle, J. A.: Influence of future climate and cropland expansion on isoprene emissions and tropospheric ozone, Atmos. Chem. Phys., 14, 1011-1024, https://doi.org/10.5194/acp-14-1011-2014, 2014.

Swann, A. L. S., Fung, I. Y., and Chiang, J. C. H.: Midlatitude afforestation shifts general circulation and tropical precipitation, P. Natl. Acad. Sci. USA, 109, 712-716, https://doi.org/10.1073/pnas.1116706108, 2012.

Tai, A. P. K. and Val Martin, M.: Impacts of ozone air pollution and temperature extremes on crop yields: Spatial variability, adaptation and implications for future food security, Atmos. Environ., 169, 11-21, https://doi.org/10.1016/j.atmosenv.2017.09.002, 2017.

Tai, A. P. K., Mickley, L. J., Heald, C. L., and Wu, S.: Effect of $\mathrm{CO}_{2}$ inhibition on biogenic isoprene emission: Implications for air quality under 2000 to 2050 changes in climate, vegetation, and land use, Geophys. Res. Lett., 40, 3479-3483, https://doi.org/10.1002/grl.50650, 2013.

Tai, A. P. K., Val Martin, M. and Heald, C. L.: Threat to Future Global Food Security from Climate Change 
and Ozone Air Pollution, Nat. Clim. Change, 4, 817-821, https://doi.org/10.1038/nclimate2317, 2014.

Taylor, K. E., Stouffer, R. J., and Meehl, G. A.: An overview of CMIP5 and the experiment design, B. Am. Meteorol. Soc., 93, 485-498, https://doi.org/10.1175/BAMS-D-11-00094.1, 2012.

Thomson, A. M., Calvin, K. V., Smith, S. J., Kyle, G. P., Volke, A., Patel, P., Delgado-Arias, S., and Bond-Lamberty, B.: RCP4.5: a pathway for stabilization of radiative forcing by 2100 , Climatic Change, 109, 77-94, https://doi.org/10.1007/s10584-011-01514, 2011.

Thornton, J. A., Wooldridge, P. J., Cohen, R. C., Martinez, M., Harder, H., Brune, W. H., Williams, E. J., Roberts, J. M., Fehsenfeld, F. C., Hall, S. R., Shetter, R. E., Wert, B. P., and Fried, A.: Ozone production rates as a function of $\mathrm{NO}_{x}$ abundances and $\mathrm{HO}_{x}$ production rates in the Nashville urban plume, J. Geophys. Res., 107, 4146, https://doi.org/10.1029/2001JD000932, 2002.

Tian, H., Ren, W., Tao, B., Sun, G., Chappelka, A., Wang, X., Pan, S., Yang, J., Liu, J., Felzer, B., Melillo, J., and Reilly, J.: Climate extremes and ozone pollution: a growing threat to China's food security, Ecosyst. Health Sustain., 2, e01203, https://doi.org/10.1002/ehs2.1203, 2016.

Tilmes, S.: GEOS5 Global Atmosphere Forcing Data. Research Data Archive at the National Center for Atmospheric Research, Computational and Information Systems Laboratory, available at: http://rda.ucar.edu/datasets/ds313.0/ (last access: 20 September 2020), 2016.

Unger, N.: Human land-use-driven reduction of forest volatiles cools global climate, Nat. Clim. Change, 4, 907-910, https://doi.org/10.1038/nclimate2347, 2014.

Val Martin, M., Heald, C. L., and Arnold, S. R.: Coupling dry deposition to vegetation phenology in the Community Earth System Model: Implications for the simulation of surface $\mathrm{O}_{3}$, Geophys. Res. Lett., 41, 2988-2996, https://doi.org/10.1002/2014GL059651, 2014.

Val Martin, M., Heald, C. L., Lamarque, J.-F., Tilmes, S., Emmons, L. K., and Schichtel, B. A.: How emissions, climate, and land use change will impact mid-century air quality over the United States: a focus on effects at national parks, Atmos. Chem. Phys., 15, 2805-2823, https://doi.org/10.5194/acp15-2805-2015, 2015.

van der Molen, M. K., van den Hurk, B. J. J. M., and Hazeleger, W.: A dampened land use change climate response towards the tropics, Clim. Dynam., 37, 2035-2043, https://doi.org/10.1007/s00382-011-1018-0, 2011.

van Vuuren, D. P., den Elzen, M. G. J., Lucas, P. L., Eickhout, B., Strengers, B. J., van Ruijven, B., Wonink, S., and van Houdt, R.: Stabilizing greenhouse gas concentrations at low levels: an assessment of reduction strategies and costs, Climatic Change, 81, 119-159, https://doi.org/10.1007/s10584-006-9172-9, 2007.

van Vuuren, D. P., Edmonds, J., Kainuma, M., Riahi, K., Thomson, A., Hibbard, K., Hurtt, G. C., Kram, T., Krey, V., Lamarque, J. F., Masui, T., Meinshausen, M., Nakicenovic, N., Smith, S. J., and Rose, S. K.: The representative concentration pathways: an overview, Climatic Change, 109, 5-31, https://doi.org/10.1007/s10584-011-0148-z, 2011.

Verbeke, T., Lathière, J., Szopa, S., and de Noblet-Ducoudré, N.: Impact of future land-cover changes on $\mathrm{HNO}_{3}$ and $\mathrm{O}_{3}$ surface dry deposition, Atmos. Chem. Phys., 15, 13555-13568, https://doi.org/10.5194/acp-15-13555-2015, 2015. von Kuhlmann, R., Lawrence, M. G., Pöschl, U., and Crutzen, P. J.: Sensitivities in global scale modeling of isoprene, Atmos. Chem. Phys., 4, 1-17, https://doi.org/10.5194/acp-4-1-2004, 2004.

Wang, L.: Datasets, availalble at: https://drive.google.com/drive/ folders/1ThA3S_jOPezgU5NDKDzy-oRHwf_CpwgA?usp= sharing, last access: 20 September 2020.

Wang, Y., Zhang, Y., Hao, J., and Luo, M.: Seasonal and spatial variability of surface ozone over China: contributions from background and domestic pollution, Atmos. Chem. Phys., 11, 35113525, https://doi.org/10.5194/acp-11-3511-2011, 2011.

Wang, Y., Shen, L., Wu, S., Mickley, L., He, J., and Hao, J.: Sensitivity of surface ozone over China to 2000-2050 global changes of climate and emissions, Atmos. Environ., 75, 374-382, https://doi.org/10.1016/j.atmosenv.2013.04.045, 2013.

Wesely, M.: Parameterization of surface resistances to gaseous dry deposition in regional-scale numerical models, Atmos. Environ., 23, 1293-1304, https://doi.org/10.1016/0004-6981(89)90153-4, 1989.

Wise, M., Calvin, K., Thomson, A., Clarke, L., Bond-Lamberty, B., Sands, R., Smith, S., J., Janetos, A., and Edmonds, J.: Implication of limiting $\mathrm{CO}_{2}$ concentrations for land use and energy, Science, 324, 1183-1186, https://doi.org/10.1126/science.1168475, 2009a.

Wise, M., Calvin, K., Thomson, A., Clarke, L., Sands, R., Smith, S. J., Janetos, A., and Edmonds, J.: The Implications of Limiting $\mathrm{CO}_{2}$ Concentrations for Agriculture, Land-use Change Emissions, and Bioenergy, Technical Report, DOE Pacific Northwest National Laboratory, Richland, WA, USA, 2009b.

Wong, A. Y. H., Tai, A. P. K., and Ip, Y.-Y.: Attribution and statistical parameterization of the sensitivity of surface ozone to changes in leaf area index based on a chemical transport model, J. Geophys. Res.-Atmos., 123, 1883-1898, https://doi.org/10.1002/2017JD027311, 2018.

Wu, S., Mickley, L. J., Kaplan, J. O., and Jacob, D. J.: Impacts of changes in land use and land cover on atmospheric chemistry and air quality over the 21 st century, Atmos. Chem. Phys., 12, 15971609, https://doi.org/10.5194/acp-12-1597-2012, 2012.

Xu, Z., Mahmood, R., Yang, Z.-L., Fu, C., and Su, H. Investigating diurnal and seasonal climatic response to land use and land cover change over monsoon Asia with the Community Earth System Model, J. Geophys. Res.-Atmos., 120, 1137-1152, https://doi.org/10.1002/2014JD022479, 2015.

Xue, L., Wang, T., Louie, P. K. K., Luk, C. W. Y., Blake, D. R., and $\mathrm{Xu}, \mathrm{Z}$.: Increasing external effects negate local efforts to control ozone air pollution: A case study of Hong Kong and implications for other Chinese cities, Environ. Sci. Technol., 48, 1076910775, https://doi.org/10.1021/es503278g, 2014.

Yienger, J. J. and Levy II H.: Empirical model of global soilbiogenic $\mathrm{NO}_{x}$ emissions, J. Geophys. Res.-Atmos., 100, 1144711464, https://doi.org/10.1029/95JD00370, 1995.

Yue, X. and Unger, N.: Ozone vegetation damage effects on gross primary productivity in the United States, Atmos. Chem. Phys., 14, 9137-9153, https://doi.org/10.5194/acp-149137-2014, 2014.

Zhang, Q., Yuan, B., Shao, M., Wang, X., Lu, S., Lu, K., Wang, M., Chen, L., Chang, C.-C., and Liu, S. C.: Variations of ground-level $\mathrm{O}_{3}$ and its precursors in Beijing in summertime between 2005 and 2011, Atmos. Chem. Phys., 14, 6089-6101, https://doi.org/10.5194/acp-14-6089-2014, 2014. 
Zhou, D., Ding, A., Mao, H., Fu, C., Wang, T., Chan, L. Y., Ding, K., Zhang, Y., Liu, J., Lu, A., and Hao, N.: Impacts of the East Asian monsoon on lower tropospheric ozone over coastal South China, Environ. Res. Lett., 8, 044011, https://doi.org/10.1088/1748-9326/8/4/044011, 2013. 